\title{
Von Willebrand Factor in Health and Disease
}

\author{
P. P. Avdonin ${ }^{a}$, N. V. Tsvetaeva ${ }^{b}$, N. V. Goncharov ${ }^{c, d}$, E. Yu. Rybakova ${ }^{a}$, \\ S. K. Trufanov ${ }^{a}$, A. A. Tsitrina ${ }^{a}$, and P. V. Avdonin ${ }^{a}$, * \\ ${ }^{a}$ Koltsov Institute of Development Biology, Russian Academy of Sciences, Moscow, 119334 Russia \\ ${ }^{b}$ National Medical Research Center of Hematology of the Ministry of Health of the Russian Federation, Moscow, 125167 Russia \\ ${ }^{c}$ Sechenov Institute of Evolutionary Physiology and Biochemistry, Russian Academy of Sciences, St. Petersburg, 194223 Russia \\ ${ }^{d}$ Scientific Research Institute of Hygiene, Occupational Pathology and Human Ecology, \\ FMBA, Kapitolovo, Leningrad oblast, 188663 Russia \\ *e-mail: pvavdonin@yandex.ru
}

Received April 15, 2021; revised April 29, 2021; accepted April 30, 2021

\begin{abstract}
Von Willebrand factor (vWF), the key component of hemostasis, is synthesized in endothelial cells and megakaryocytes and released into the blood as high molecular weight multimeric glycoproteins weighing up to 20 million Daltons. Blood plasma metalloprotease ADAMTS13 cleaves ultra-large vWF multimers to smaller multimeric and oligomeric molecules. The vWF molecules attach to the sites of damage at the surface of arterioles and capillaries and unfold under conditions of shear stress. On the unfolded vWF molecule, the regions interacting with receptors on the platelet membrane are exposed. After binding to the vWF filaments, platelets are activated; platelets circulating in the vessels are additionally attached to them, leading to thrombus formation, blocking of microvessels, and cessation of bleeding. This review describes the history of the discovery of vWF, presents data on the mechanisms of vWF secretion and its structure, and characterizes the processes of vWF metabolism in the body under normal and pathological conditions.
\end{abstract}

Keywords: von Willebrand factor, endothelium, pathology, von Willebrand disease, thrombotic microangiopathies

DOI: $10.1134 / \mathrm{S} 1990747821040036$

\section{HISTORY OF THE DISCOVERY OF VON WILLEBRAND FACTOR AND METALLOPROTEASE ADAMTS13}

The key component of the system of hemostasis, von Willebrand factor (vWF), was named after the physician Erik Adolf von Willebrand (1.02.187012.12.1949), who graduated from the Imperial Alexander University in Helsingfors (Helsinki) and worked in Finland after the collapse of the Russian Empire. In 1924, von Willebrand was asked to examine a 5-year-old girl from a village on the Aland Islands, who suffered from bleeding. Girl's relatives, from both father's and mother's side, were prone to heavy bleeding even after the slightest damage to skin and mucous membranes. It caused the death of four out of 11 brothers and sisters of the girl at an early age. In 1926, based on the results of his studies, Erik von Willebrand published an article in Swedish on the previously unknown form of inherited hemophilia, which is characterized by normal blood clotting but prolonged bleeding time [1]. He termed this disorder as pseudohemophilia. Later on, it was named after him as von Willebrand disease (see review [2]). The girl examined by Erik von Willebrand died at the age of 13 during a fourth menstrual period. Erik von Willebrand described one of the most severe forms of this disorder. By now it has been shown that von Willebrand disease has about 20 variants, from almost inconspicuous to extremely severe. In addition to inherited forms, there are the acquired forms of von Willebrand disease.

Bleeding from small vessels, which is the main symptom of von Willebrand disease, normally stops as a result of platelet attachment to the damaged surface and microthrombus formation. Whole blood or plasma transfusion from a healthy person stops the bleeding caused by this disease [3]. In the late 1950s, the blood plasma fraction that shortens the duration of bleeding was obtained by cryoprecipitation. The fraction contained blood clotting factor VIII; however, the ability to shorten the duration of bleeding was also typical of cryoprecipitate from the plasma of patients with hemophilia A [4]. The unknown active plasma component was termed as von Willebrand factor. The study of its nature required a model system simulating the bleeding from small vessels and its arrest. Originally, blood was pumped through a plastic tube filled with glass beads of $0.5 \mathrm{~mm}$ in diameter $[5,6]$. The adhesive properties of platelets were evaluated by their retention in the blood flow. Platelet retention time in the blood of patients with von Willebrand disease was 
shorter, but it could be corrected if the plasma of healthy donors, hemophilia A patients, cryoprecipitates or partially purified plasma fractions was preliminarily passed through the glass bead filter (see review [7]). This test system was used to determine the vWF activity in protein fractions during gel filtration; hence, a fairly well purified vWF preparation was obtained, to which antibodies were developed $[8,9]$. The latter were used to demonstrate the multimeric structure of vWF on an electrophoregram [10]. Immunoprecipitation has shown that factor VIII and vWF are different substances [11]. The multimers of vWF are separated in agarose gel $[12,13]$. Multimeric proteins are formed as a result of cross-linking of dimeric molecules via disulfide bonds. In the dimers per se, monomeric proteins are also linked by a disulfide bond [14]. In blood plasma, vWF is a mixture of such multimers with the molecular weight distribution from about 500 thousand (a single dimer) to 20 million Daltons and even more. The structure of vWF will be considered in more detail below.

The study of vWF was largely promoted by the discovery of ristocetin-induced platelet aggregation in blood plasma [15]. Platelet aggregation occurs in platelet-rich plasma from healthy donors under stirring in the presence of ristocetin, though there is no aggregation in the plasma of patients with von Willebrand disease. Ristocetin-induced platelet aggregation assay is used to quantify the vWF activity in blood plasma of patients with suspected von Willebrand disease. In this case, one can use the washed and formaldehyde-fixed platelets, which maintain the ability to agglutinate in the presence of ristocetin and normal plasma. Later it was shown that ristocetin induced partial unfolding of high-molecular multimers, which enabled von Willebrand factor binding to platelets. Patients suffering from type 2 von Willebrand disease, with the normal level of vWF antigen but the lower activity, were revealed for the first time in 1972 [16]. Botrocetin, a snake venom protein, exerts an effect similar to that of ristocetin [17].

In the United States, slightly prior to the discovery of the disease associated with vWF deficiency by Erik von Willebrand, Eli Moschcovitz published an article describing a disease with the precisely opposite pathogenic mechanism [18]. He described for the first time the case of thrombotic thrombocytopenic purpura (TTP), or Moschcovitz syndrome, which is caused by vWF hyperactivity in plasma. A 16-year-old girl had multiple hemorrhages on the surface of the body (petechiae), then hemolysis was followed by paralysis, loss of consciousness and death. Postmortem examination showed numerous small hyaline (glass-like) thrombi in the arterioles and capillaries of different organs. The relationship between this pathology and vWF began to clear up after had been shown in 1982 that the plasma of TTP patients in remission contained large amounts of thrombogenic ultra-large vWF multimers [19]. During disease recurrence, on the contrary, the proportion of ultra-large vWF multimers decreases and the relative amount of small multimers increases. The higher content of ultra-large multimers in the case of TTP suggested the absence of or decrease in their cleavage in the plasma of patients. Giant vWF multimers are cleaved into smaller oligomers by metalloprotease ADAMTS13 (a disintegrinlike and metalloprotease with thrombospondin type 1 motifs). This enzyme was found by two laboratories: in 1997 in Switzerland [20] and a year later in the United States [21]. ADAMTS 13 degrades multimers by breaking the peptide bonds of vWF between tyrosine and methionine residues 1605 and 1606 in monomeric subunits. The leading cause of TTP is the generation of IgG antibodies blocking the activity of this enzyme [22]. In case of another form of thrombotic microangiopathy (TMA), hemolytic uremic syndrome (HUS), the increase in vWF activity is caused by the increase in its production by endothelium but not by suppression of its degradation. During HUS recurrence, the level of the vWF antigen increases several times, also with the predominance of small vWF olgomers, but in contrast to TTP, HUS remission is not accompanied by multimeric composition shifting towards highmolecular multimers [23]. In addition to TTP and HUS, other forms of TMA with an increase in vWF activitry are described. The etiology of TMA is not always established.

\section{SYNTHESIS OF VON WILLEBRAND FACTOR}

Being one of the key components of the hemostatic system, vWF is synthesized in endothelial cells and in megakaryocytes giving rise to platelets. $\mathrm{vWF}$ is secreted into blood and provides platelet attachment to the damaged vascular wall through binding with collagen, as well as performs the function of carrier protein for blood clotting factor VIII [24]. The initial monomeric protein, from which the multimeric chain of vWF is formed, is encoded by the gene localized on chromosome 12p2.1 [25]. The VWF gene is approximately 178 kilobase pairs $(\mathrm{kbp})$ in length and contains 52 exons [26], and 17 of them encode the signaling peptide and propeptide of VWF (the so-called von Willebrand factor antigen II). The size of exons varies from 40 to $1379 \mathrm{bp}$; the size of introns varies from 97 to $19.9 \mathrm{kbp}$. The mature subunit of vWF and the 3 '-untranslated region are encoded by the part of the gene including approximately $80 \mathrm{kbp}$. The haploid human genome has a single specimen of the vWF gene [27]. Expression is controlled by transcription factor GATA2 [28].

The primary vWF gene product is formed by 2813 amino acids (AA) and includes a signaling peptide of 22 AA and a propeptide of 741 AA [29-31]. The domain structure of the vWF monomer with numerous regions, where glycosylation occurs, is shown in Fig. 1. The process of maturation of the multimeric molecule of vWF and its secretion in endothelial cells is as follows. Glycosylation of vWF molecule through 


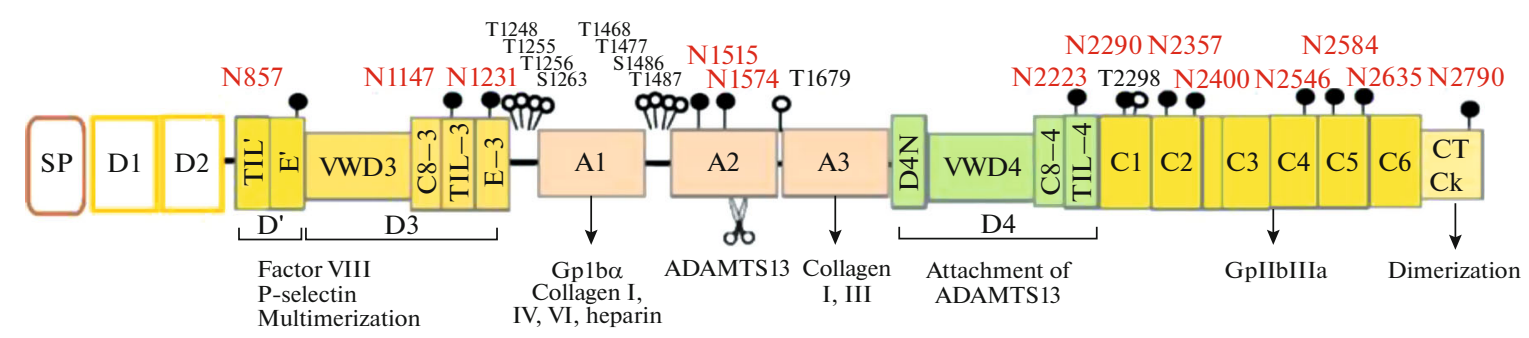

Fig. 1. Domain structure of the monomer of mature von Willebrand factor. The scheme shows the sites of interaction on the vW molecule with factor VIII, P-selectin, with GP1b $\alpha$, GPIIbIIIa, with collagens of types I, III, IV, VI, sites of ADAMTS13 attachment, sites of vWV cleavage, sites at which dimerization and multimerization of vWF occurs. TIL' is trypsin inhibitor-like domain. Glycosyl residues are shown as black (N-glycans) and white (O-glycans) balls on the stems. Glycosylation occurs at the following amino acid residues: arginine (N), threonine (T) and serine (S). Adapted from [30] and [90].

the attachment of large mannose residues begins in rough endoplasmic reticulum. The mature glycosylated monomer of $260 \mathrm{kDa}$ forms a dimer in the endoplasmic reticulum via C-terminal disulfide bonds and moves by the anterograde pathway to the Golgi apparatus. The mass of the monomer increases to $275 \mathrm{kDa}$ due to further growth of glycosyl residues. It is followed by vWF multimerization, propeptide cleavage in the most of monomers, and the start of helix formation. The monomer mass decreases to $220 \mathrm{kDa}$; however, the monomers of $275 \mathrm{kDa}$ are maintained in some secreted vWF multimers. The formed vWF multimers enter the trans-cisterns of the Golgi complex (transGolgi network), where the tubules of vWF multimers, which begin to form, can already be seen in an electron microscope [32]. The vesicles detaching from the Golgi complex are transformed into structures typical of only endothelial cells: Weibel-Palade bodies, cigarshaped due to the effect of helical tubules formed by the growing vWF multimers [33, 34]. The volume occupied by the multimers decreases by 2 orders of magnitude as a result of helix formation $[35,36]$. The diameter of Weibel-Palade bodies is $100-200 \mathrm{~nm}$; the length is 1 to $5 \mu \mathrm{m}$. The molecular weight of vWF multimers in mature bodies can be more than 20 million Daltons [36]. The ultra-large vWF multimers secreted by endothelial cells are cleaved into smaller fragments by the ADAMTS13 protease present in the plasma [37]. The experiments in vivo have shown that vWF multimers in mesenteric arteries of mice with the ADAMTS13 gene knockout line up in a row and link to each other to form filaments of 20 to $100 \mu \mathrm{m}$ in length attached to the cells in response to the activation of endothelial cells [38-40]. When the platelets are stained with rhodamine, one can see that they attach to these filaments like beads. In cultivated endothelial cells from the human umbilical vein, the length of filaments formed by the bundles of vWF molecules is up to $1 \mathrm{~mm}$ and more [39]. These filaments can form a cross-linked structure, which is not formed in vivo. The attachment of vWF filaments to the membrane of cultivated endothelial cells involves $\mathrm{P}$-selectin and $\alpha \mathrm{V} \beta 3$ integrin [38].
In addition to vWF, Weibel-Palade bodies contain proteins such as P-selectin, interleukin-8, osteoprotegerin, angiopoietin-2, and endothelin-1 [41, 42]. P-selectin and angiopoietin-2 are stored in different fractions of Weibel-Palade bodies [43]. Moreover, there is evidence that the release of vWF and P-selectin from Weibel-Palade bodies is differently regulated [34]. It has been shown that $\mathrm{P}$-selectin is expressed together with vWF only in some of the cultivated endothelial cells from human aorta [44]. Factor VIII is also secreted by not all vWF-producing endothelial cells [45]. Physiological effects of the proteins and peptides secreted from Weibel-Palade bodies are considered in the review [42].

In platelets, vWF is localized in spherical alphagranules. There, vWF is also packed as tubules of 200250 Angstrom in diameter with eccentric localization [46].

\section{REGULATION OF EXOCYTOSIS OF VON WILLEBRAND FACTOR}

The secretion of vWF in endothelial cells is a result of constitutive and regulated exocytosis of WeibelPalade bodies [45, 47, 48]. In addition to these two, there is a third mechanism of exocytosis with the involvement of autophagosomes [49]. vWF exocytosis is activated under various conditions including inflammation, vascular disruption, hypoxia, shear stress, and activation of membrane receptors [42, 50, 51]. Regulated exocytosis occurs mostly in the apical direction; constitutive exocytosis occurs in both apical and basal directions $[40,52]$.

It is supposed that constitutive exocytosis occurs during the release of the contents of single WeibelPalade bodies. The vWF released thereby in complex with factor VIII is necessary for maintaining normal homeostasis. It has been shown that several WeibelPalade bodies simultaneously release their vWF into special secretory vesicles (secretory pods) as a result of exocytosis activation by histamine and thrombin. vWF molecules present in secretory pods in large amounts are combined into bundles, which form plateletcatching filaments on the surface of endothelium [38]. 
Second messengers cAMP and $\mathrm{Ca}^{2+}$ are involved in the transmission of the action of agonists on vWF secretion $[40,53]$. Thrombin and histamine activating the $\mathrm{Ca}^{2+}$-signaling system show a more marked activation of vWF exocytosis [54-56] compared to adrenaline and vasopressin acting via cAMP $[57,58]$. Moreover, adrenaline and vasopressin, in contrast to histamine and thrombin, do not trigger or weakly activate the exocytosis of Weibel-Palade bodies containing P-selectin in addition to VWF [59]. The mechanism of exocytosis of Weibel-Palade bodies is not fully understood, but some basic signaling mechanisms triggering this process are known. Both $\mathrm{Ca}^{2+}$ ions and cAMP activate the conversion of GDP into GTP in the RalA protein under the influence of RalGDS [60, 61]. RalA acting via phospholipase D (PLD) stimulates the SNARE-mediated Weibel-Palade bodies fusion with the plasma membrane [62]. In this process, alphasynuclein regulates the activity of RalA and can prevent the fusion of Weibel-Palade bodies with the membrane [63]. The transduction of activating signal from cAMP, in addition to protein kinase A, involves Epac via the Rap $1 \rightarrow$ PREX1 $\rightarrow$ Rac $1 \rightarrow$ PLD signaling pathway [40].

The regulation of exocytosis also occurs at an earlier stage: during the transport of Weibel-Palade bodies along microtubules. The attachment of Rab27A to Weibel-Palade bodies via MyRIP and MyoVa proteins is followed by their "anchoring" on actin filaments, thereby preventing the exocytosis of immature molecules $[64,65]$. In addition to binding to the actin cytoskeleton, Rab27A regulates the exocytosis of Weibel-Palade bodies by attaching effector proteins Slp-4a and Munc14-3 [66-69]. Slp-4a and Munc14-3 are necessary for fusion of Weibel-Palade bodies with plasma membrane. The regulation of exocytosis also involves Rab15, Rab3B and Rab3D [69] and syntaxin-3 [70, 71]. Destruction of mucrotubules inhibits $\mathrm{Ca}^{2+}$ dependent exocytosis, while destabilization of actin, on the contrary, intensifies it $[55,67,72]$. In the case of cAMP-induced exocytosis, these effects are not observed. Calcium ions activate the transport of Weibel-Palade bodies towards the membrane; when $\mathrm{Ca}^{2+}$ concentration in the cytoplasm of endothelial cells increases, vWF is completely released from the cells. In contrast, vWF is released only partially upon an increase in the cAMP level [53, 57, 73]. Interestingly, the agonists activating adenylate cyclase trigger the accumulation of Weibel-Palade bodies in the juxtanuclear region of the cells (see review [42]).

In recent years, yet more evidence of relationship between inflammation and thromboses has been obtained [74, 75]. Thrombosis can be induced by reactive oxygen species generated during inflammation. Previously it has been shown that vWF secretion is stimulated by superoxide anion [76]. With regard to the effect of hydrogen peroxide (the product of dismutation of superoxide anion) on vWF secretion, the data are contradictory. The studies presented in [76] did not show such effect of $\mathrm{H}_{2} \mathrm{O}_{2}$. Contrariwise, Yang et al. [77] presented the data on a 1.5-2-fold increase in vWF secretion under the influence of exogenous $\mathrm{H}_{2} \mathrm{O}_{2}$ at a rather high concentration of $0.5 \mathrm{mM}$. In our studies, we proceeded from the assumption that thrombus formation during inflammation is determined not by the circulating vWF but rather by vWF multimers attached to the surface of activated endothelium. Therefore, we studied the effect of hydrogen peroxide on the expression of vWF multimers on the surface of human umbilical vein endothelial cells (HUVEC). We used two methods for staining vWF on the membrane: using antibodies [78] and using a fluorescentlylabeled aptamer binding to domain A1 in the vWF molecule [79]. It was revealed that hydrogen peroxide at a physiologically relevant concentration $(100 \mu \mathrm{M})$ resulted in a 2-4-fold increase in the exposure of vWF on the membrane of endothelial cells. The formation of vWF filaments of tens micrometers in length has been demonstrated. Thus, the data suggest the role of $\mathrm{H}_{2} \mathrm{O}_{2}$ in thrombus formation in case of inflammatory processes. In addition to the entry of exogenous hydrogen peroxide into endothelial cells, it is formed inside the cells under the influence of VEGF [80], TNF $\alpha$ [81]. Both of these agonists activate vWF exocytosis [82, 83]. Hence it can be assumed that $\mathrm{H}_{2} \mathrm{O}_{2}$ is involved as a second messenger in the vWF endocytosis triggered by these agonists.

\section{STRUCTURE OF VON WILLEBRAND FACTOR}

The initial vWF monomer is formed by domains D1-D2-D'-D3-A1-A2-A3-D4-C1-C2-C3-C4-C5-

C6-CK. D-domains are formed by smaller modules that can be seen in electron photographs $[45,84]$. The key element of the vWF monomer is formed by A domains: the $\mathrm{A} 1$ domain provides $\mathrm{vWF}$ binding to the GPIb $\alpha$ receptor on the platelet membrane; in the A2 domain, there is an ADAMTS13-cleaved peptide bond, the hydrolysis of which regulates the size of vWF multimer in blood flow; and finally, the A3 domain is responsible for the attachment to collagen at the site of vascular endothelial injury. The disulfide bridge between the $\mathrm{N}$ - and $\mathrm{C}$-termini of the $\mathrm{A} 1$ and $\mathrm{A} 3$ domains fixes each of these domains in a relatively rigid configuration. On the contrary, the A2 domain has no rigid structure and stretches under the conditions of rapid blood flow at a high shear stress, which makes it available for proteolysis [85]. The binding of the A3 domain to collagens I and III, which are localized in the subendothelial space, occurs due to electrostatic interaction between negatively charged amino acid residues in the peptide chain of the A3 domain and positively charged residues in collagens. The Van der Waals interaction is poorly expressed [86]. This fact explains the low affinity of the A3 domain to collagen and the need of simultaneous attachment of vWF to collagen through several regions 
for tight adhesion. It seems that partially due to this reason, ultra-large multimers are more thrombogenic. Domains D1, D2, D3 include the following modules: VWD (von Willebrand D domain), C8, TIL and Emodule. Domain D' does not contain VWD and C8 module, and D4 lacks the E-module and has the D4N subdomain. In the vWF sequence, there is an unusually high content of cysteine residues $(8.3 \%)$. It is 4 -fold higher than for proteins on the average. It is supposed that the most part of cysteine residues form disulfide bonds, which are rearranged during vWF multimer maturation and helix formation [87]. The functions of the domains are described in detail in the reviews [88, 89].

Due to formation of disulfide bonds, first there is the cross-linking of vWF monomers into dimers and then the formation of multimeric vWF molecules from the dimers. Protodimers are formed as a result of cross-linking of two primary monomers by three disulfide bonds between cysteine residues 2771, 2773 and 2811 localized in the C-terminal region of the peptide chain. These disulfide bridges are structurally protected against reduction, which provides the strength of vWF dimers. Being in vesicles of the Golgi apparatus at acidic $\mathrm{pH}$ values, protodimers structurally look like a bouquet of flowers with two intertwined "stems" formed by domains A2-A3-D4-C1C2-C3-C4-C5-C6 and "flowers" of domains D1-D2D'-D3-A1 [84]. The next stage is covalent cross-linking of the protodimers by two disulfide bonds between cysteines 889 and 898 in D3-domains at the N-termini of polypeptide chains. After the formation of multimers, furin (a cellular endoprotease) cleaves $\mathrm{N}$-terminal tails of the monomers.

The multimeric structure of vWF is detected by agarose gel electrophoresis at an agarose concentration of 1 to $2-3 \%$ [13]. Ultra-large multimerse can be seen during gel electrophoresis at the minimum concentration of agarose. According to the results of electrophoresis, the maximum mass of multimers formed in endothelial cells is 20 and more million Daltons, which corresponds to the mass of 35-40 dimers [45]. The separation of small components can be improved by adding acrylamide to the gel composition. This method made it possible to detect low-molecular proteins in patients with type IIA von Willebrand disease [13]. Ultra-large vWF multimers can spontaneouly bind to platelets, in contrast to medium- and smallseized vWF molecules, which are attached to platelets only in the presence of ristocetin or botrocetin [91]. According to the model proposed by Guria et al. [92, 93], the higher thrombogenic activity of ultra-large vWF multimers in vessels is accounted for by the lower threshold of shear stress, when their unfolding takes place.

In the normal plasma, the multimeric composition of $\mathrm{vWF}$ is regulated by metalloprotease ADAMTS13 cleaving the $\mathrm{Tyr}^{1605}$ - Met ${ }^{1606}$ bond in A2 domain [94].
Recent studies have demonstrated that some other proteases in plasma, including plasmin, are able to cleave vWF multimers [95]. Plasmin cleaves the bond between amino acid residues K1491-R1492 in the polypeptide chain region linking domains A1 and A2.

\section{GLYCOSYLATION AND SIALYLATION OF VON WILLEBRAND FACTOR}

Within the entire period from the moment when a monomer is formed till the secretion of giant multimers, a posttranslational modification of vWF takes place, namely glycosylation [96]. After the process is completed, the mass of $N$ - and $O$-glycans reaches $20 \%$ of the final mass of vWF [90]. Glycans attach to arginine residues ( $N$-glycans), and also to serine and threonine residues $(O$-glycans). The structural analysis of the vWF monomer originally showed 13 potential sites of $\mathrm{N}$-glycosylation; the subsequent mass-spectrometric studies demonstrated the presence of $12 \mathrm{~N}$-glycans [97]. The attachment of the primary oligosaccharide $\left(\mathrm{Glc}_{3} \mathrm{Man}_{9} \mathrm{GlcNAc}_{2}\right)$ to arginine occurs in the reticulum; then, first in the reticulum and later in the Golgi apparatus, there is remodeling and construction of a branched structure of glycosyl $N$-glycans [96]. After the cleavage of two extreme glucose residues by glucosidases, the monomer binds to lectins in the reticulum via calnexin and calreticulin, with its subsequent folding. When the folding is completed, the protein is further transported to the Golgi apparatus, where the modification of $\mathrm{N}$-glycans continues. Finally, complex heterogeneous carbohydrate structures are formed with the involvement of numerous glycosyltransferases. Three groups of $N$-glycans are formed: mannose-rich glycans most similar to the initial structure, hybrid glycans, and complex glycans with di-, triand tetra-antennary chains. The dominant forms are mono- and di-sialylilated di-antennary complex $\mathrm{N}$-glycans. $15 \%$ of $\mathrm{N}$-glycans have the determinants of $\mathrm{ABO}(\mathrm{H})$ blood groups. $80 \%$ of sialic acids in the vWF molecule are attached to $N$-linked glycans and $20 \%$ of them are attached to $O$-linked glycans.

Serine- or threonine-bound oligosaccharides ( $O$-glycans) are synthesized via successive glycosylation already after the release of vWF from the Golgi complex [96]. Structurally, $O$-glycans are much simpler than $N$-glycans. Only $1 \%$ of them carry the ABO determinants of blood groups.

Endothelial cells are the main source of vWF circulating in blood [98]. The vWF secreted by platelets, according to the experiments in vitro, remains bound to the receptors on the platelet membrane $[99,100]$. In blood plasma, sialic acid residues are gradually cleaved by neuraminidases from glycosyl residues on the vWF molecule. This process occurs with vWF aging. Desialylized vWF has a higher functional activity compared to the initial one: it causes spontaneous platelet aggregation and stronger binding of platelets to collagen under shear stress [90]. 
It is interesting to note that $\mathrm{vWF}$ in platelets considerably differs in glycosylation pattern from this glycoprotein in endothelial cells and from vWF circulating in blood [98]. The platelet vWF is much more depleted in sialylated $N$-glycans and lacks the blood group determinants [96]. The platelet vWF has a weaker bond with GPIb $\alpha$ and stronger bonds with the GPIIb/IIIa integrin and heparin.

\section{PLATELET BINDING TO VON WILLEBRAND FACTOR}

Platelets contain two vWF-binding receptors: glycoprotein Ib-IX-V (GPIb-IX-V) complex and integrin $\alpha \operatorname{IIb} \beta 3$ (GPIIb-IIIa). The subendothelial surface with attached vWF filaments is exposed at the sites of vascular injuries. In microvessels or in places of narrowing of the arteries, under the conditions of high shear stress, there is unfolding of the multimeric molecules of vWF attached to the surface, and their regions are exposed corresponding to the peptide chain from Leu480/Val-481 to Gly-718 of the primary monomer molecule [101]. The GPIb-IX-V complex on the platelet membrane interacts with these sequences on the vWF molecule. Recognition of the GPIb-IX-V complex is provided by the Asp-514-Glu-542 region within these sites [17]. The second vWF receptor on the platelet surface is integrin $\alpha \mathrm{IIb} \beta 3$ (GPIIb-IIIa). vWF and fibrinogen bind to GPIIb-IIIa, forming molecular bridges between the aggregating platelets. The quantity of GPIIb-IIIa on the platelet surface correlates with the degree of ADP-induced aggregation of platelets in healthy donors and patients with acute coronary syndrome [102]. At a low shear stress in the absence of fibrinogen, both receptors provide vWF attachment during platelet aggregation [103]. At a high shear stress, the interaction between vWF and GPIb-IX-V becomes an important factor of aggregation [104]. Kaneva et al. [105] proposed a mathematical model describing the role of $\mathrm{vWF}$ receptors in adhesion and subsequent thrombosis.

The vWF receptor GPIb-IX-V is expressed only in platelets at a quantity of approximately 25000 receptor complexes per cell. GPIb-IX-V consists of 2 subunits of GPIb $\alpha$, GP1b $\beta$, GPIX and 1 subunit of GPV [35]. vWF binds to region 1-282 of the extracellular part of GPIb $\alpha$. In the vWF molecule, the GPIb $\alpha$ binding site is localized in the A1 domain. In addition to vWF, the ligands for GPIb $\alpha$ are also thrombospondin, factor XII, factor XI, thrombin, high-molecular-weight kininogen, P-selectin, and Mac-1. The interaction between vWF and glycoprotein Ib-IX-V is not confined to the passive attachment of platelets to this protein complex. GPIb $\alpha$ interacts via its cytoplasmic tail domain (Phe568-Trp570) with the PI3 kinase, the actin-binding protein flamin, and the adapter protein 14-3-3 $\zeta$. The vWF binding to GPIb-IX-V causes platelet activation and transition of integrin $\alpha \operatorname{IIb} \beta 3$ from low- to high-affinity state, when it is able to interact with the $\mathrm{C} 4$ domain in the vWF monomer. It contributes to stable attachment of vWF to platelets and their spreading. The issue of how the vWF/GPIbIX-V interaction promotes platelet activation remains not fully understood. Different signaling pathways are triggered depending on shear stress values. The GPIbIX-V-induced platelet activation was shown to involve several intracellular molecules: Src kinases, Rac1, PI3K/Akt, a cGMP-dependent protein kinase (PKG), and the MAP kinases [35].

\section{THE FATE OF VON WILLEBRAND FACTOR IN BLOOD PLASMA}

As has been mentioned above, endothelial cells are continuously secreting vWF to blood plasma on the apical side and to the intercellular space on the basolateral side. After the cells have been activated by agonists, vWF secretion to blood increases. Under the normal conditions of blood flow, the vWF filaments released from secretory bubbles accumulating vWF from several Weibel-Palade bodies are cleaved by protease ADAMTS13 [39]. Ultra-large multimers are also partially cleaved in plasma when they are unfolded in a fast flow. As a result, the balance between the large multimers, the medium and small oligomeric forms of vWF is maintained. Sadler [106] presents the mean value for the level of vWF antigen in plasma: about $100 \mathrm{IU} / \mathrm{dL}$. According to the data of other researchers [107], the level of vWF antigen in healthy donors is 61 IU/dL (95\% CI: 51-91 IU/dL). One international unit (IU) corresponds to $10 \mu \mathrm{g}$ of vWF. Thus, if the $v W F$ level is expressed in other units ( $\mu \mathrm{g}$ per $\mathrm{mL}$ ), the average value is about $10 \mu \mathrm{g} / \mathrm{mL}$; in people with the $\mathrm{O}$ (I) blood group, it is lower by 20-25\% [108, 109]. Desmopressin, the analog of vasopressin with the substitution of $D$-arginine for $L$-arginine, which acts via V2 receptors [110], causes an actually immediate 2-fold increase in the level of vWF antigen in human blood plasma, which is maintained for no less than $2 \mathrm{~h}$ and returns to the normal level in $24 \mathrm{~h}$. The introduction of histamine or endothelin-1 to healthy donors increased the plasma level of vWF by $11 \%$ [111] and 19\% [112], respectively. Very marked changes are observed during systemic inflammation caused by intravenous administration of $2 \mathrm{ng} / \mathrm{kg}$ endotoxin to healthy volunteers. The level of the vWF antigen increased by $259 \%$ in $4 \mathrm{~h}$ and by $192 \%$ in $24 \mathrm{~h}$ and returned to the normal value after 7 days [113]. The effect of agonists acvtivating endothelial cells on secretion of other proteins localized in Weibel-Palade bodies has been studied. The entry of protegerin into blood does not vary upon the introduction of desmopressin and increases twofold in response to lipopolysaccharide [114]. This fact suggests that desmopressin and lipopolysaccharide in vivo cause exocytosis from different populations of Weibel-Palade bodies. Desmopressin stimulates the secretion of vWF into blood but does not induce the entry of P-selectin into blood [107], which also con- 
firms the effect of this agonist on an individual population of Weibel-Palade bodies.

The vWF lifespan varies from 4.2 to $26 \mathrm{~h}$ (shorther in group $\mathrm{O}(\mathrm{I})$ than in $\mathrm{AB}(\mathrm{IV})$ ) [35]. The release of vWF from plasma was supposed to occur after its cleavage by metalloproteinase ADAMTS13. However, different methods showed that it is not true. In patients with type 1 von Willebrand disease or hemophilia A, the rate of decrease in the vWF level after administration of desmopressin does not depend on the activity of ADAMTS13 [115]. The experiments in the ADAMTS- $13^{+/+}$and ADAMTS- $13^{-/-}$mice have also shown that the rate of vWF release does not depend on the presence of this enzyme in blood [116].

According to the available data, the clearance of vWF occurs as a result of its capture by macrophages and endothelial cells of the renal sinuses and hepatocytes (see review [117]), with macrophages playing the key role. When radiolabeled vWF is introduced into mouse blood, it accumulates mostly in the liver and, in much lower amounts, in the spleen and kidneys [118, 119]. The rate of removal of large and small multimers was the same.

When vWF is captured by macrophages, endotheliocytes and hepatocytes, it first binds to receptors on the plasma membrane. vWF is attached by two types of receptors: lectins and scavenger receptors [117]. vWF binding by lectins and subsequent clearance depend on the presence of sialic acid in glycosyl residues. Sialic acid protects vWF from being captured by some types of lectin receptors [120-122]. vWF with desialilated glycans binds to the MGL (macrophage galactose-type lectin) receptor in macrophages [123] and with the AMR (Ashwell-Morell receptor) in hepatocytes [124, 125]. The importance of MGL for $\mathrm{vWF}$ clearance is prevailing. The MGL and AMR receptors bind to $\beta$ - $D$-galactose and $\mathrm{N}$-acetyl- $D$-galactosamine. These carbohydrate residues are unmasked after the cleavage of sialic acid during vWF aging. The MGL receptor also attached hyposialized vWF [123, 126]. The lectin-type receptor binding the sialized vWF is expressed in macrophages in addition to MGL and AMR. This is a Siglec-5 lectin (sialic-acid binding immunoglobulin-like lectin) [127, 128]. It is also present in neutrophils and T cells [129]. The vWF receptor CLEC4M (C-type lectin domain family 4 member M) specifically binding mannose [130] is expressed in the endothelial cells of liver sinusoids and in lymph nodes [131].

The scavenger receptors that capture vWF include receptors LRP1 (lipoprotein receptor-related protein-1) [132] and SR-A1 (scavenger receptor class A member I) [133] in macrophages and stabilin-2 in the endothelial cells of liver sinusoids [134]. vWF binds to the LRP1 regions localized in the A1A2A3 domains [135]. The presence of $\mathrm{N}$-glycans protects $\mathrm{VWF}$ from phagocytosis by the liver and spleen macrophages mediated by LRP1 receptors. The regulation of $\mathrm{vWF}$ binding to
SR-Al involves the region of the peptide chain of the D'D3 domains, domain A1 and domain D4 [136].

The vWF content in platelets is $15-20 \%$ of the total amount of vWF in blood, or $2.8 \mu \mathrm{g}$ per $10^{9}$ platelets [99]. vWF is secreted from alpha granules upon platelet activation by ADP, collagen, or thrombin [137]. The experiments with pigs have shown that vWF secretion from platelets has no appreciable effect on the total level of vWF in plasma [98]. The vWF secreted from alpha granules remains attached to platelets in the presence of calcium ions in the medium $[99,100]$. The amount of vWF secreted by platelets could be determined when a chelator of divalent cations is added. In a calcium-free medium in vitro, the concentration of free vWF under conditions of platelet activation in suspension can increase up to $50 \mathrm{IU} / \mathrm{dL}$, or $5 \mu \mathrm{g} / \mathrm{mL}$ [138]. The platelet vWF plays a key role in platelet adhesion to collagen under shear stress conditions [98]. The experiments with pigs have shown that the platelet vWF, in contrast to vWF circulating in plasma, is not directly involved in arterial thrombus formation [139].

\section{IMPAIRED EXCHANGE OF VON WILLEBRAND FACTOR AS A CAUSE OF PATHOLOGICAL BLEEDING AND THRMOBOSES}

The curve of the frequency distribution of vWF levels (IU/dl) for the population is an asymmetrical bellshaped, with $95 \%$ of all the values lying within the range of 50 to $200 \mathrm{IU} / \mathrm{dL}$ (Fig. 2) [106]. The population analysis shows the enhanced risk of thrombosis and bleeding at extremely high and extremely low vWF levels, respectively. As has been mentioned above, the average level of vWF in human plasma varies between people with different blood groups, not allowing the accurate detection of its referent boundaries. The mutations in the vWF gene leading to the lower vWF production have been revealed. The approximate dependence between the presence of mutations and the content of vWF antigen in plasma is shown with a thin line (Fig. 2). As shown below, the more objective criterion for detecting a pathological condition is determination of the multimeric composition and activity of vWF in the agglutination test with ristocetin [140].

\section{VON WILLEBRAND DISEASE}

Von Willebrand disease can be caused by low vWF levels in blood plasma or by structural and functional impairments in the vWF molecule [29, 140]. Von Willebrand disease is the most common hereditary blood clotting disorder. It is characterized by frequent hematomes (subcutaneous hemorrhages), abnormally prolonged bleeding after minor injuries and bleeding from mucosal surfaces, including gastrointestinal mucus. There are at least 20 variants of von Willebrand disease [29]. They are subdivided into 3 types. The 


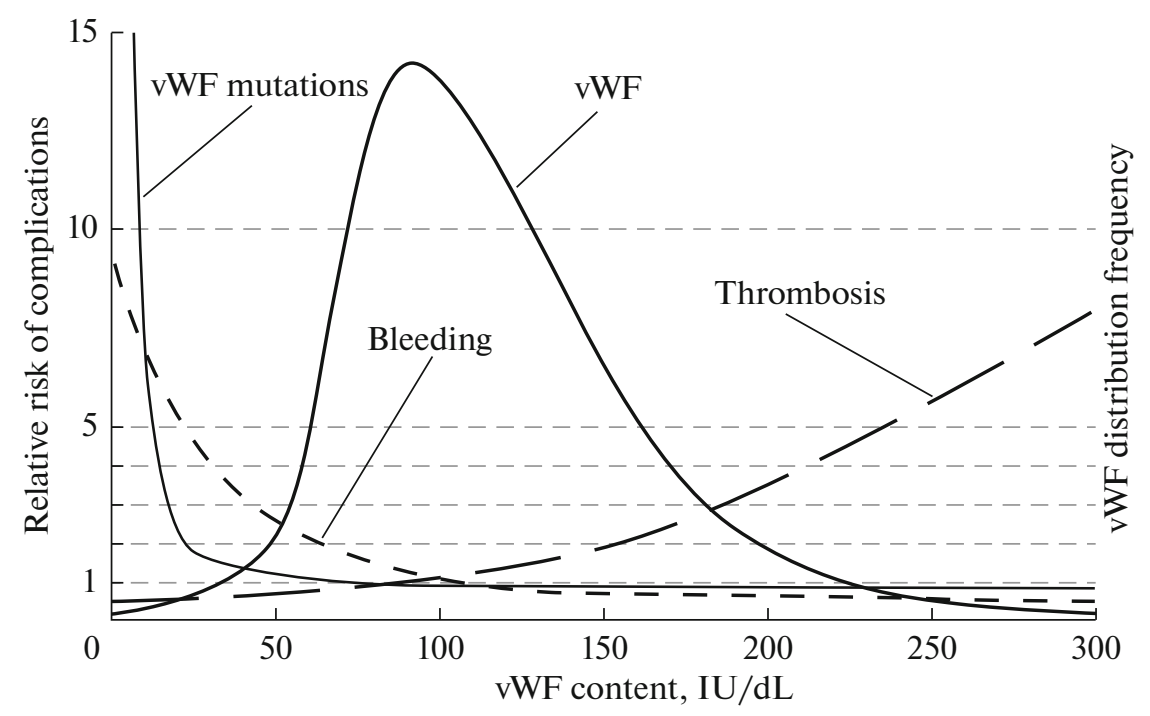

Fig. 2. Relationship between the plasma level of vWF, the risk of development of bleeding or thrombosis, and mutations in the vWF gene. Dashed lines show the relations between the plasma level of the vWF antigen and a relative risk of bleeding or thrombosis. Thin solid line shows the dependence between mutations in the vWF gene and vWF production. The relative risk of bleeding or thrombosis is taken as a unit at the vWF level of $100 \mathrm{IU} / \mathrm{dL}$. Adapted from [106].

sign of type 1 is a low plasma level of vWF, less than $30 \mu \mathrm{g} / \mathrm{mL}$ [141]. The ratio of vWF multimers in type 1 von Willebrand disease corresponds to the normal value (Fig. 3a). The vWF level can decrease due to reduced $v W F$ synthesis/secretion [142] or more rapid clearance of vWF [141]. Type 1 von Willebrand disease is generally characterized by autosomal dominant inheritance. More than 10 mutations causing the development of this type of the disease have been described [143]. Most of them cause a decrease in vWF secretion by the endothelium.

In type 3 von Willebrand disease with autosomal recessive inheritance, there is almost no vWF in plasma (Fig. 3c). The plasma concentration of vWF below $3 \mu \mathrm{g} / \mathrm{mL}$ is considered a diagnostic feature of type 3 von Willebrand disease. Type 3 von Willebrand disease is characterized by a dramatic decrease in the level of blood clotting factor VIII. More than 80 mutations of different origin are known to lead to this type of pathology [144].

Type 2 von Willebrand disease is caused by mutations leading to the structural and functional changes in vWF. The multimeric composition of vWF in different forms of type 2 von Willebrand disease has been described in some publications [145-147]. The subtypes of type 2 von Willebrand disease are as follows: 2A (autosomal dominant and autosomal recessive), 2B (autosomal dominant), 2M (autosomal dominant), and $2 \mathrm{~N}$ (autosomal recessive) [148]. In the 2A, 2B and $2 \mathrm{~N}$ subtypes, the relative levels of ultra-large and large vWF multimers in plasma are reduced. Figure $3 \mathrm{~b}$ shows an example of the multimeric composition of vWF in type 2 von Willebrand disease. The classifica- tion of the inherited forms of von Willebrand disease is presented in the review [149].

Type $2 \mathrm{~A}$ is characterized by the lower affinity of vWF to platelets due to a decrease in the level of highmolecular vWF multimers in plasma. This pathology is associated with more than 50 different missense mutations leading to the two types of pathogenetic mechanisms: impaired biosynthesis of vWF dimers or multimers (group 1 mutations), or to biosynthesis of a protein with enhanced susceptibility to proteolysis by metalloproteinase ADAMTS13 (group 2 mutations) [144]. Group 1 mutations lead to amino acid substitutions in the vWF propeptide, in the D3 and A2 domains, and at the C-terminus of mature vWF subunit. The mutations resulting in the accelerated proteolysis of vWF are localized in the region of exon 28 encoding the A2 domain.

Type 2B von Willebrand disease includes pathological forms with the enhanced affinity of vWF to platelet glycoprotein 1B. The mutations cause amino acid substitutions in the A1 domain and are also localized in exon 28 [144]. In the 2B-type, there is a spontaneous vWF binding to platelets and release of large multimers from blood circulation.

Type $2 \mathrm{M}$ includes vWF variants with the lower affinity to platelets at the normal ratio of multimers. It is determined by the amino acid substitution impairing the folding of the A1 domain loop and thereby resulting in the lower affinity to platelet glycoprotein $1 \mathrm{~b}[150]$.

Type $2 \mathrm{~N}$ (Normandy) is caused by mutations in the factor VIII binding site localized in the D' and D3 domains at the N-terminus of vWF molecules [151]. This phenotype is most frequently caused by the 


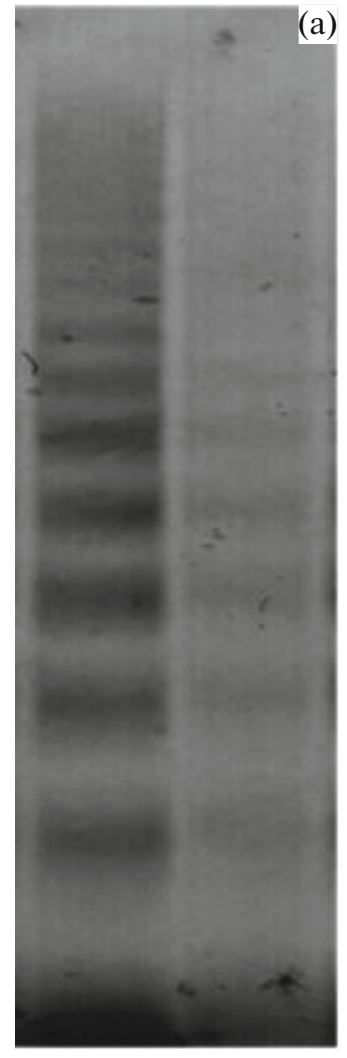

$\mathrm{C}$

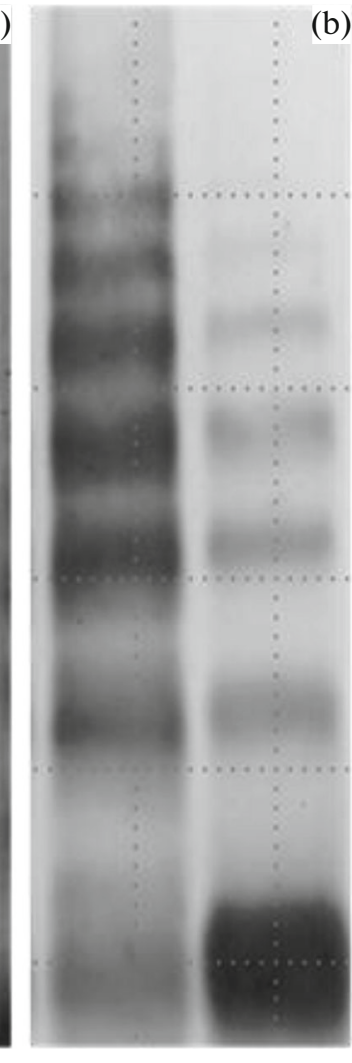

C II

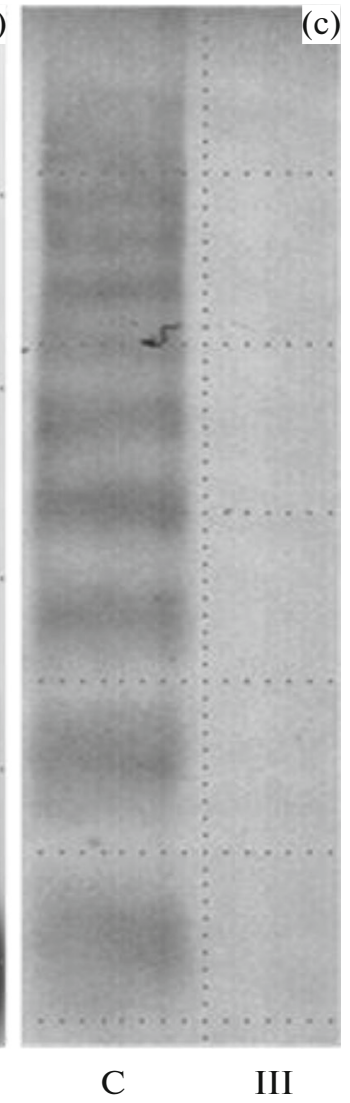

(c)

Fig. 3. Multimeric composition of von Willebrand factor, characteristic for type I (a), II (b), and III (c) von Willebrand disease. $\mathrm{C}, \mathrm{vWF}$ multimers in the plasma of healthy donors. Electrophoresis was performed in $1.5 \%$ agarose; proteins were transferred to a nitrocellulose membrane, incubated with the antibodies against vWF and horseradish peroxidase-conjugated second antibody. Dithionitrobenzoate was used for development.

R854Q mutation. In the 2N-type, there are no minor bands in the triplets of vWF multimers, while the secretion and levels of large multimers are reduced.

The relative number of patients with different types of von Willebrand disease has been analyzed in France (the total number of established cases is 1167 from 670 families). It has been shown that there are $25 \%$ of type 1 patients, $8 \%$ of type 3 patients, $66 \%$ of type 2 patients (2A: 18\%, 2B: 17\%, 2M: 19\%, 2N: 12\%), and $1 \%$ of patients with an undefined form [152].

Acquired von Willebrand disease in some cases is caused by the cleavage of ultra-large vWF multimers under the conditions of high shear stress [153]. With respect to the multimeric composition of $\mathrm{vWF}$, this form is similar to type 2A von Willebrand disease. This form of acquired von Willebrand disease is observed in case of aortic stenosis and is accompanied by bleeding in the gastrointestinal tract [154]. A decrease in the vWF level can be due to formation of autoantibodies, and in some cases they selectively target vWF in the activated state [155]. The acquired form of von Willebrand disease can be associated with lymphoproliferative and myeloproliferative disorders.

\section{WILLEBRAND FACTOR METABOLISM IN THROMBOTIC MICROANGIOPATHIES}

Inhanced activity of vWF in blood plasma caused by an increase in the proportion of thrombogenic high-molecular-weight multimers of vWF at a normal level of the vWF secretion or due to a general increase in the vWF supply to plasma from the endothelium is the cause of thrombosis in thrombotic microangiopathies [106, 156]. Thrombotic microangiopathies (TMA) include the congenital (Upshaw-Schulman syndrome) or autoimmune forms of thrombotic thrombocytopenic purpura (TTP), the TMA caused by cancer, infections, transplantation, chemotherapy and some drugs, as well as the hemolytic uremic syndrome (HUS) associated with the Shiga toxin-producing E. coli infection and an atypical HUS caused by inherited or acquired disorders of the complement system [157]. During pregnancy and in the postpartum period, there are cases of the HELLP syndrome and pre-eclampsia associated TMA [158]. In the case of autoimmune TTP, the ADAMTS13 activity drops below $10 \%$ of the normal level. The decrease is caused by the production of inhibitory autoantibodies against ADAMTS13. In other forms of TMA, the ADAMTS13 activity does 


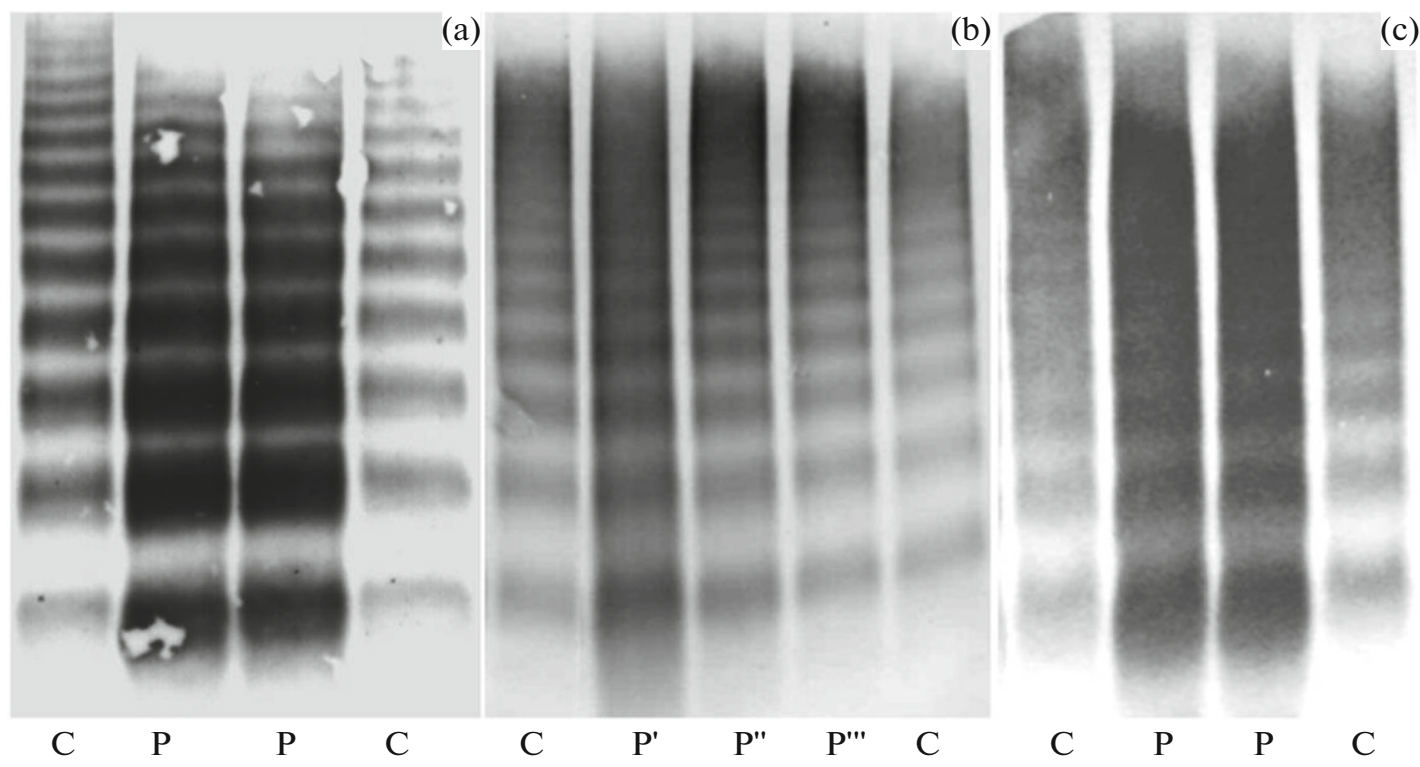

Fig. 4. The multimeric composition of vWF in blood plasma of the patient with TMA of unclear etiology (a), the TTP patient (b), and a terminal cancer patient (c). P, the plasma of the patients; C, the control plasma of healthy donors. P', P", P"' are patient's plasma before and in 10 and 20 days after starting the plasma exchange. The conditions of electrophoresis and analysis of the multimeric composition of vWF are described in the legends to Fig. 3.

not decrease below 20\% [159]. We have studied the multimeric composition of vWF in a patient with TMA of unclear etiology and in a patient with autoimmune TTP developed in late pregnancy and after delivery, as well as in a cancer patient at the terminal stage (Fig. 4). The ADAMTS13 activities in the TMA and autoimmune TTP patients were $53 \%$ and less than $5 \%$ of the normal value, respectively (Fig. 5a). These values were determined in the acute period of disease. In the blood plasma of the TMA patient, there was a noticeable increase in the vWF level as can be seen from brightness of the bands of vWF multimers (Fig. 4a). The increased vWF level in the plasma of this patient could probably be a result of its enhanced production caused by an inflammatory response in the endothelium. However, it is clearly seen that the relative content of ultra-large multimers dramatically decreases. The lower proportion of ultra-large multimers, against the enhanced total level of the vWF antigen, is caused by their consumption during thrombus formation in microvessels. An analogous situation can be observed at the terminal stage of a cancer disease (Fig. 4c). The plasma level of the vWF antigen in the patient was much higher, but proportion of the thrombogenic ultra-large vWF multimers was dramatically decreased (Fig. 4c).

Figure $4 \mathrm{~b}$ shows the electrophoregrams of $\mathrm{vWF}$ multimers in the plasma of the autoimmune TTP patient at a peak of severity of clinical manifestations, as well as 10 and 20 days after intensive plasma exchange sessions. The clinical manifestations of TTP appeared at the end of pregnancy and increased after delivery: hemolytic crisis with the lactate dehydroge- nase (LDH) activity exceeding 20 normal values, thrombocytopenia, the presence of schistocytes in the blood smear; the neurological disorders proceeded to coma. At that moment, the analysis of vWF multimer composition showed a decrease in the relative content of ultra-large and large multimers (Fig. 4b). However, there was no increase in the level of the vWF antigen compared to the control, like in the TMA patient (Fig. 4a). On the contrary, the content of the vWF antigen in the acute phase did not exceed the normal average level, which is, according to various sources, from 6.1 [107] to $10 \mu \mathrm{g} / \mathrm{mL}$ [106]. The changes in the multimeric composition of vWF became apparent 10 days after effective plasma exchanges. The bands of ultra-large multimers appeared and their relative content increased, which was considered as inhibition of thrombus formation. The latter was also indicated by cessation of hemolysis, increase in the number of platelets in the patient's blood from $(20-30) \times 10^{9}$ to $120 \times 10^{9} / \mathrm{L}$, and normalization of the LDH activity. The multimeric composition of vWF became even closer to the normal value 20 days after starting the plasma exchange. The brightness of the bands decreased, demonstrating the lower level of the vWF antigen, but the higher level of ultra-large multimers was maintained. The changes in the multimeric composition of vWF correlated with the data from quantification of the antigen and the vWF activity (Fig. 5b). As it was mentioned above, at the peak of the disease, the plasma level of the vWF antigen and the vWF activity determined in the ristocetin agglutination assay actually did not exceed the normal value. A slight increase in the concentration of the vWF antigen 
(a)

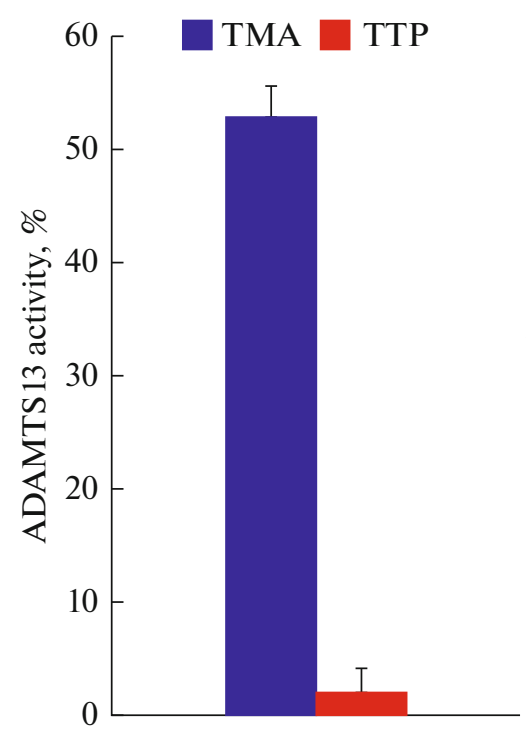

(b)

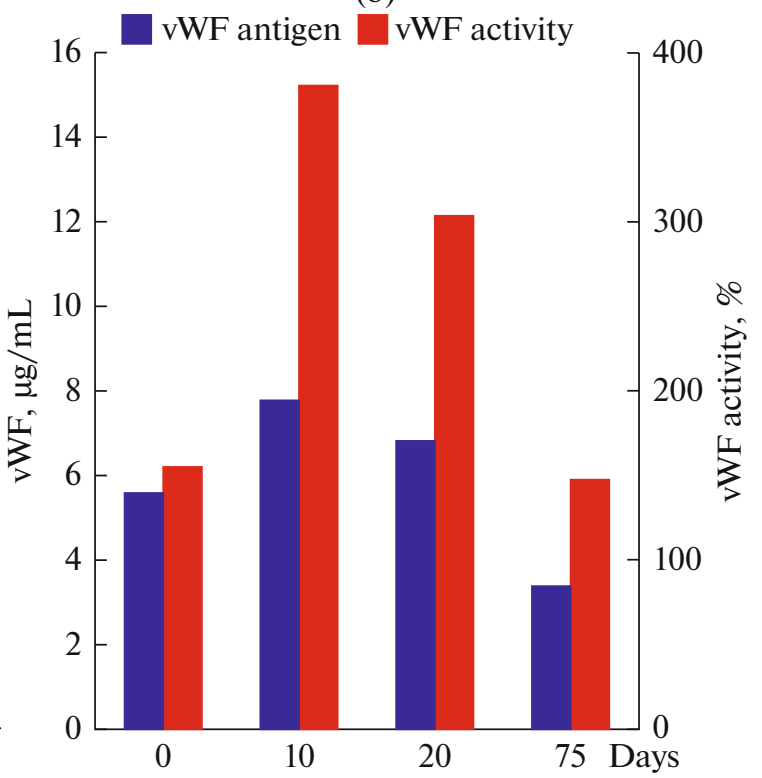

Fig. 5. (a) The ADAMTS13 activity in blood plasma of the patient with TMA of unclear etiology and the patient with TTP. (b) The content of the vWF antigen and the vWF activity in the plasma of the patient with TTP before starting (0) and 10, 20 and 75 days after starting the plasma exchange. The ADAMTS13 and vWF activities are expressed as \% of the mean values of these indices in healthy donors. The vWF activity was determined in the ristocetin-induced platelet aggregation test.

occurred 10 days after starting the plasma exchange. However, in the same period there was a dramatic increase in the vWF activity, reflecting the appearance of thrombogenic ultra-large multimers in plasma. In 20 days, there was a gradual decrease in the vWF activity; in 2.5 months, the vWF activity returned to the initial, almost normal value, while the antigen content decreased below the initial level.

A common sign of all the three pathological conditions is a decrease in the proportion of ultra-large $\mathrm{vWF}$ multimers, which are consumed during thrombus formation, at the moment of exacerbation. The causes of initial increase in the level of ultra-large thrombogenic vWF multimers are different. In case of autoimmune TTP, the amount of secreted vWF, as is can be seen from the presented data, does not exceed the normal value; however, against the zero activity of ADAMTS13, the system is less stable, because the ratio of multimers is initially shifted towards ultra-large forms, and thrombosis is initiated more easily. In case of TMA of unclear etiology and cancer disease at the terminal stage, there seems to be a hyperproduction of vWF. It is still unclear what triggers thrombus formation, because only the presence of ultra-large multimers is insufficient for this event. There are data on the relationship between thrombosis and inflammatory processes in vessels [74]. In particular, the complement factor C5a is known to cause exocytosis of P-selectin and $\mathrm{vWF}$ [160]. However, discussion of this problem is beyond the framework of this review.

\section{CONCLUSIONS}

Almost 100 years have passed since the discovery of diseases associated with the impaired metabolism of von Willebrand factor. Since that time it has been shown that this unique glycoprotein, which has many multimeric forms and varies among individuals with respect to glycosylation pattern and polymorphism, plays the crucial role in the normal functioning of an organism and in pathogenesis of many diseases [161]. The von Willebrand factor has been intensively studied over the past years. The vWF genetic forms and transformation pathways in blood plasma have been characterized; it has been shown how these processes are related to pathogenesis of particular variants of von Willebrand disease and autoimmune thrombotic thrombocytopenic purpura. The least studied issue seems to be as follows: what determines the excessive secretion of vWF, which apparently causes extremely severe forms of thrombotic microangiopathy that do not always respond to effective treatment. Moreover, the question about additional factors initiating thrombosis at enhanced vWF activity in plasma also needs further investigation.

\section{ACKNOWLEDGMENTS}

The authors are grateful to Professor A.V. Mazurov for his valuable comments when discussing this article. and to Dr. E.E. Efremov for his assistance in determining the plasma level of the vWF antigen. The work was supported by the Russian Science Foundation (project no. 21-15-00441). 


\section{COMPLIANCE WITH ETHICAL STANDARDS}

The authors declare that they have no conflict of interest.

This article does not contain any studies involving animals or human participants performed by any of the authors.

\section{OPEN ACCESS}

This article is licensed under a Creative Commons Attribution 4.0 International License, which permits use, sharing, adaptation, distribution and reproduction in any medium or format, as long as you give appropriate credit to the original author(s) and the source, provide a link to the Creative Commons licence, and indicate if changes were made. The images or other third party material in this article are included in the article's Creative Commons licence, unless indicated otherwise in a credit line to the material. If material is not included in the article's Creative Commons licence and your intended use is not permitted by statutory regulation or exceeds the permitted use, you will need to obtain permission directly from the copyright holder. To view a copy of this licence, visit http://creativecommons.org/licenses/by/4.0/.

\section{REFERENCES}

1. von Willebrand A. 1926. Hereditar pseudohemofili. Finska Lakarsallskapetes Handl. 67, 7-112.

2. Favaloro E. J. 2014. Diagnosing von Willebrand disease: A short history of laboratory milestones and innovations, plus current status, challenges, and solutions. Semin. Thromb. Hemost. 40, 551-570. https://doi.org/10.1055/s-0034-1383546

3. Nilsson I.M., Blomback M., Jorpes E., Blomback B., Johansson S.A. 1957. Von Willebrand's disease and its correction with human plasma fraction 1-0. Acta Med. Scand. 159, 179-188. https://doi.org/10.1111/j.0954-6820.1957.tb00123.x

4. Cornu P., Larrieu M.J., Caen J., Bernard J. 1963. Transfusion studies in von Willebrand's disease: Effect on bleeding time and factor VIII. Br. J. Haematol. 9, 189-202.

https://doi.org/10.1111/j.1365-2141.1963.tb05457.x

5. Hellem A.J. 1960. The adhesiveness of human blood platelets in vitro. Scand. J. Clin. Lab. Invest. 12 Suppl, $1-117$.

6. Bowie E.J., Owen C.A., Jr., Thompson J.H., Didisheim P. 1969. Platelet adhesiveness in von Willebrand's disease. Am. J. Clin. Pathol. 52, 69-77. https://doi.org/10.1093/ajcp/52.1.69

7. Bouma B.N., Van Mourik J.A. 2006. Unraveling the mystery of von Willebrand factor. J. Thromb. Haemost. 4, 489-495. https://doi.org/10.1111/j.1538-7836.2006.01813.x

8. Bouma B.N., Wiegerinck Y., Sixma J.J., Van Mourik J.A., Mochtar I.A. 1972. Immunological characterization of purified anti-haemophilic factor A (factor VIII) which corrects abnormal platelet retention in Von Willebrand's disease. Nat. New Biol. 236, 104-106. https://doi.org/10.1038/newbio236104a0

9. Zimmerman T.S., Ratnoff O.D., Powell A.E. 1971. Immunologic differentiation of classic hemophilia (factor 8 deficiency) and von Willebrand's dissase, with observa- tions on combined deficiencies of antihemophilic factor and proaccelerin (factor $\mathrm{V}$ ) and on an acquired circulating anticoagulant against antihemophilic factor. J. Clin. Invest. 50, 244-254. https://doi.org/10.1172/JCI106480

10. van Mourik J.A., Bouma B.N., LaBruyere W.T., de Graaf S., Mochtar I.A. 1974. Factor VIII, a series of homologous oligomers and a complex of two proteins. Thromb. Res. 4, 155-164. https://doi.org/10.1016/0049-3848(74)90211-4

11. Zimmerman T.S., Edgington T.S. 1973. Factor VIII coagulant activity and factor VIII-like antigen: Independent molecular entities. J. Exp. Med. 138, 1015-1020. https://doi.org/10.1084/jem.138.4.1015

12. Meyer D., Obert B., Pietu G., Lavergne J.M., Zimmerman T.S. 1980. Multimeric structure of factor VIII/von Willebrand factor in von Willebrand's disease. J. Lab. Clin. Med. 95, 590-602.

13. Ruggeri Z.M., Zimmerman T.S. 1981. The complex multimeric composition of factor VIII/von Willebrand factor. Blood. 57, 1140-1143.

14. Counts R.B., Paskell S.L., Elgee S.K. 1978. Disulfide bonds and the quaternary structure of factor VIII/von Willebrand factor. J. Clin. Invest. 62, 702-709. https://doi.org/10.1172/JCI109178

15. Howard M.A., Firkin B.G. 1971. Ristocetin - a new tool in the investigation of platelet aggregation. Thromb. Diath. Haemorrh. 26, 362-369.

16. Holmberg L., Nilsson I.M. 1972. Genetic variants of von Willebrand's disease. Br. Med. J. 3, 317-320. https://doi.org/10.1136/bmj.3.5822.317

17. Berndt M.C., Ward C.M., Booth W.J., Castaldi P.A., Mazurov A.V., Andrews R.K. 1992. Identification of aspartic acid 514 through glutamic acid 542 as a glycoprotein Ib-IX complex receptor recognition sequence in von Willebrand factor. Mechanism of modulation of von Willebrand factor by ristocetin and botrocetin. Biochemistry. 31, 11144-11151. https://doi.org/10.1021/bi00160a027

18. Moschcowitz E. 1925. An acute febrile pleiochromic anemia with hyaline thrombosis of the terminal arterioles and capillaries: An undescribed disease. Arch. Intern. Med. 36, 89-93.

19. Moake J.L., Rudy C.K., Troll J.H., Weinstein M.J., Colannino N.M., Azocar J., Seder R.H., Hong S.L., Deykin D. 1982. Unusually large plasma factor VIII: von Willebrand factor multimers in chronic relapsing thrombotic thrombocytopenic purpura. N. Engl. J. Med. 307, 1432-1435. https://doi.org/10.1056/NEJM198212023072306

20. Furlan M., Robles R., Solenthaler M., Wassmer M., Sandoz P., Lammle B. 1997. Deficient activity of von Willebrand factor-cleaving protease in chronic relapsing thrombotic thrombocytopenic purpura. Blood. 89, 3097-3103.

21. Tsai H.M., Lian E.C. 1998. Antibodies to von Willebrand factor-cleaving protease in acute thrombotic thrombocytopenic purpura. N. Engl. J. Med. 339, 1585-1594. https://doi.org/10.1056/NEJM199811263392203

22. Kwaan H.C., Bennett C.L. 2005. Thrombotic thrombocytopenic purpura-2005. Semin. Thromb. Hemost. 31, 611-614.

https://doi.org/10.1055/s-2005-925466 
23. Moake J.L., Byrnes J.J., Troll J.H., Rudy C.K., Weinstein M.J., Colannino N.M., Hong S.L. 1984. Abnormal VIII: von Willebrand factor patterns in the plasma of patients with the hemolytic-uremic syndrome. Blood. 64, 592-598.

24. Terraube V., O’Donnell J.S., Jenkins P.V. 2010. Factor VIII and von Willebrand factor interaction: Biological, clinical and therapeutic importance. Haemophilia. 16, $3-13$. https://doi.org/10.1111/j.1365-2516.2009.02005.x

25. Verweij C.L., de Vries C.J., Distel B., van Zonneveld A.J., van Kessel A.G., van Mourik J.A., Pannekoek H. 1985. Construction of cDNA coding for human von Willebrand factor using antibody probes for colony-screening and mapping of the chromosomal gene. Nucleic Acids Res. 13, 4699-4717. https://doi.org/10.1093/nar/13.13.4699

26. Mancuso D.J., Tuley E.A., Westfield L.A., Worrall N.K., Shelton-Inloes B.B., Sorace J.M., Alevy Y.G., Sadler J.E. 1989. Structure of the gene for human von Willebrand factor. J. Biol. Chem. 264, 19514-19527.

27. Collins C.J., Underdahl J.P., Levene R.B., Ravera C.P., Morin M.J., Dombalagian M.J., Ricca G., Livingston D.M., Lynch D.C. 1987. Molecular cloning of the human gene for von Willebrand factor and identification of the transcription initiation site. Proc. Nat.l Acad. Sci. USA. 84, 4393-4397.

https://doi.org/10.1073/pnas.84.13.4393

28. Jahroudi N., Lynch D.C. 1994. Endothelial-cell-specific regulation of von Willebrand factor gene expression. Mol. Cell. Biol. 14, 999-1008.

29. Tuddenham E.G. 1989. von Willebrand factor and its disorders: An overview of recent molecular studies. Blood Rev. 3, 251-262.

30. Gogia S., Neelamegham S. 2015. Role of fluid shear stress in regulating VWF structure, function and related blood disorders. Biorheology. 52, 319-335. https://doi.org/10.3233/BIR-15061

31. Lenting P.J., Casari C., Christophe O.D., Denis C.V. 2012. von Willebrand factor: The old, the new and the unknown. J. Thromb. Haemost. 10, 2428-2437. https://doi.org/10.1111/jth.12008

32. Zenner H.L., Collinson L. M., Michaux G., Cutler D.F. 2007. High-pressure freezing provides insights into Weibel-Palade body biogenesis. J. Cell. Sci. 120, 21172125. https://doi.org/10.1242/jcs.007781

33. Wagner D.D., Marder V.J. 1984. Biosynthesis of von Willebrand protein by human endothelial cells: Processing steps and their intracellular localization. J. Cell. Biol. 99, 2123-2130. https://doi.org/10.1083/jcb.99.6.2123

34. Nightingale T.D., McCormack J.J., Grimes W., Robinson C., Lopes da Silva M., White I.J., Vaughan A., Cramer L.P., Cutler D.F. 2018. Tuning the endothelial response: Differential release of exocytic cargos from Weibel-Palade bodies. J. Thromb. Haemost. 16, 18731886. https://doi.org/10.1111/jth.14218

35. Bryckaert M., Rosa J.P., Denis C.V., Lenting P.J. 2015. Of von Willebrand factor and platelets. Cell. Mol. Life Sci. 72, 307-326.

https://doi.org/10.1007/s00018-014-1743-8
36. Huang R.H., Wang Y., Roth R., Yu X., Purvis A.R., Heuser J.E., Egelman E.H., Sadler J.E. 2008. Assembly of Weibel-Palade body-like tubules from N-terminal domains of von Willebrand factor. Proc. Natl. Acad. Sci. USA. 105, 482-487.

https://doi.org/10.1073/pnas.0710079105

37. Dong J.F., Whitelock J., Bernardo A., Ball C., Cruz M.A. 2004. Variations among normal individuals in the cleavage of endothelial-derived ultra-large von Willebrand factor under flow. J. Thromb. Haemost. 2, 14601466. doi JTH830 https://doi.org/10.1111/j.1538-7836.2004.00830.x

38. De Ceunynck K., De Meyer S.F., Vanhoorelbeke K. 2013. Unwinding the von Willebrand factor strings puzzle. Blood. 121, 270-277. https://doi.org/10.1182/blood-2012-07-442285

39. Dong J.F., Moake J.L., Nolasco L., Bernardo A., Arceneaux W., Shrimpton C.N., Schade A.J., McIntire L.V., Fujikawa K., Lopez J.A. 2002. ADAMTS-13 rapidly cleaves newly secreted ultralarge von Willebrand factor multimers on the endothelial surface under flowing conditions. Blood. 100, 4033-4039.

https://doi.org/10.1182/blood-2002-05-1401

40. Mourik M., Eikenboom J. 2017. Lifecycle of WeibelPalade bodies. Hamostaseologie. 37, 13-24. https://doi.org/10.5482/HAMO-16-07-0021

41. van Breevoort D., van Agtmaal E.L., Dragt B.S., Gebbinck J.K., Dienava-Verdoold I., Kragt A., Bierings R., Horrevoets A.J., Valentijn K.M., Eikenboom J.C., Fernandez-Borja M., Meijer A.B., Voorberg J. 2012. Proteomic screen identifies IGFBP7 as a novel component of endothelial cell-specific Weibel-Palade bodies. J. Proteome Res. 11, 2925-2936. https://doi.org/10.1021/pr300010r

42. Rondaij M.G., Bierings R., Kragt A., van Mourik J.A., Voorberg J. 2006. Dynamics and plasticity of WeibelPalade bodies in endothelial cells. Arterioscler. Thromb. Vasc. Biol. 26, 1002-1007.

https://doi.org/10.1161/01.ATV.0000209501.56852.6c

43. Fiedler U., Scharpfenecker M., Koidl S., Hegen A., Grunow V., Schmidt J. M., Kriz W., Thurston G., Augustin H. G. 2004. The Tie-2 ligand angiopoietin-2 is stored in and rapidly released upon stimulation from endothelial cell Weibel-Palade bodies. Blood. 103, 4150-4156. https://doi.org/10.1182/blood-2003-10-3685

44. Byzova T.V., Romanov Iu.A., Blasik T.N., Mazurov A.V. 1995. Interaction of a monoclonal antibody to P-selectin with activated platelets and endothelial cells. Heterogeneity of expressing P-selectin in human aorta endothelial cells. Biokhimia (Rus.). 60, 1292-1301.

45. Lenting P.J., Christophe O.D., Denis C. V. 2015. von Willebrand factor biosynthesis, secretion, and clearance: Connecting the far ends. Blood. 125, 2019-2028. https://doi.org/10.1182/blood-2014-06-528406

46. Cramer E.M., Meyer D., le Menn R., Breton-Gorius J. 1985. Eccentric localization of von Willebrand factor in an internal structure of platelet alpha-granule resembling that of Weibel-Palade bodies. Blood. 66, 710-713.

47. Valentijn K.M., van Driel L.F., Mourik M.J., Hendriks G.J., Arends T.J., Koster A.J., Valentijn J.A. 2010. Multigranular exocytosis of Weibel-Palade bodies in vascular endothelial cells. Blood. 116, 1807-1816. https://doi.org/10.1182/blood-2010-03-274209 
48. Valentijn K.M., Eikenboom J. 2013. Weibel-Palade bodies: A window to von Willebrand disease. J. Thromb. Haemost. 11, 581-592. https://doi.org/10.1111/jth.12160

49. Torisu T., Torisu K., Lee I.H., Liu J., Malide D., Combs C.A., Wu X.S., Rovira, II, Fergusson M.M., Weigert R., Connelly P.S., Daniels M.P., Komatsu M., Cao L., Finkel T. 2013. Autophagy regulates endothelial cell processing, maturation and secretion of von Willebrand factor. Nat. Med. 19, 1281-1287. https://doi.org/10.1038/nm.3288

50. Antonova O. A., Loktionova S. A., Golubeva N. V., Romanov Y. A., Mazurov A. V. 2007. Damage and activation of endothelial cells during in vitro hypoxia. Bull. Exp. Biol. Med. 144, 504-506. https://doi.org/10.1007/s10517-007-0362-X

51. Okhota S., Melnikov I., Avtaeva Y., Kozlov S., Gabbasov Z. 2020. Shear stress-induced activation of von Willebrand factor and cardiovascular pathology. Int. J. Mol. Sci. 21.

https://doi.org/10.3390/ijms21207804

52. Lopes da Silva M., Cutler D.F. 2016. von Willebrand factor multimerization and the polarity of secretory pathways in endothelial cells. Blood. 128, 277-285. https://doi.org/10.1182/blood-2015-10-677054

53. Rondaij M.G., Bierings R., Kragt A., van Mourik J.A., Voorberg J. 2006. Dynamics and plasticity of WeibelPalade bodies in endothelial cells. Arterioscler. Thromb. Vasc. Biol. 26, 1002-1007.

https://doi.org/10.1161/01.ATV.0000209501.56852.6c

54. Sporn L.A., Marder V.J., Wagner D.D. 1986. Inducible secretion of large, biologically potent von Willebrand factor multimers. Cell. 46, 185-190. https://doi.org/10.1016/0092-8674(86)90735-X

55. Vischer U.M., Barth H., Wollheim C.B. 2000. Regulated von Willebrand factor secretion is associated with agonist-specific patterns of cytoskeletal remodeling in cultured endothelial cells. Arterioscler. Thromb. Vasc. Biol. 20, 883-891.

56. Birch K.A., Pober J.S., Zavoico G.B., Means A.R., Ewenstein B.M. 1992. Calcium/calmodulin transduces thrombin-stimulated secretion: Studies in intact and minimally permeabilized human umbilical vein endothelial cells. J. Cell. Biol. 118, 1501-1510. https://doi.org/10.1083/jcb.118.6.1501

57. Vischer U.M., Wollheim C.B. 1997. Epinephrine induces von Willebrand factor release from cultured endothelial cells: Involvement of cyclic AMP-dependent signalling in exocytosis. Thromb. Haemost. 77, 11821188 .

58. Kaufmann J.E., Oksche A., Wollheim C.B., Gunther G., Rosenthal W., Vischer U.M. 2000. Vasopressin-induced von Willebrand factor secretion from endothelial cells involves V2 receptors and cAMP. J. Clin. Invest. 106, 107-116. https://doi.org/10.1172/JCI9516

59. Cleator J.H., Zhu W.Q., Vaughan D.E., Hamm H.E. 2006. Differential regulation of endothelial exocytosis of P-selectin and von Willebrand factor by protease-activated receptors and cAMP. Blood. 107, 2736-2744. https://doi.org/10.1182/blood-2004-07-2698

60. Rondaij M.G., Bierings R., van Agtmaal E.L., Gijzen K.A., Sellink E., Kragt A., Ferguson S.S., Mertens K., Hannah M.J., van Mourik J.A., Fernandez-Borja M.,
Voorberg J. 2008. Guanine exchange factor RalGDS mediates exocytosis of Weibel-Palade bodies from endothelial cells. Blood. 112, 56-63. https://doi.org/10.1182/blood-2007-07-099309

61. de Leeuw H.P., Wijers-Koster P.M., van Mourik J.A., Voorberg J. 1999. Small GTP-binding protein RalA associates with Weibel-Palade bodies in endothelial cells. Thromb. Haemost. 82, 1177-1181.

62. Valentijn K.M., Sadler J.E., Valentijn J.A., Voorberg J., Eikenboom J. 2011. Functional architecture of WeibelPalade bodies. Blood. 117, 5033-5043. https://doi.org/10.1182/blood-2010-09-267492

63. Kim K.S., Park J.Y., Jou I., Park S.M. 2010. Regulation of Weibel-Palade body exocytosis by alpha-synuclein in endothelial cells. J. Biol. Chem. 285, 21416-21425. https://doi.org/10.1074/jbc.M110.103499

64. Rojo Pulido I., Nightingale T.D., Darchen F., Seabra M.C., Cutler D.F., Gerke V. 2011. Myosin Va acts in concert with Rab27a and MyRIP to regulate acute von Willebrand factor release from endothelial cells. Traffic. 12, 1371-1382.

https://doi.org/10.1111/j.1600-0854.2011.01248.X

65. Conte I.L., Hellen N., Bierings R., Mashanov G.I., Manneville J.B., Kiskin N.I., Hannah M.J., Molloy J.E., Carter T. 2016. Interaction between MyRIP and the actin cytoskeleton regulates Weibel-Palade body trafficking and exocytosis. J. Cell. Sci. 129, 592-603. https://doi.org/10.1242/jcs.178285

66. Holthenrich A., Drexler H. C.A., Chehab T., Nass J., Gerke V. 2019. Proximity proteomics of endothelial Weibel-Palade bodies identifies novel regulator of von Willebrand factor secretion. Blood. 134, 979-982. https://doi.org/10.1182/blood.2019000786

67. Nightingale T.D., Pattni K., Hume A.N., Seabra M.C., Cutler D.F. 2009. Rab27a and MyRIP regulate the amount and multimeric state of VWF released from endothelial cells. Blood. 113, 5010-5018. https://doi.org/10.1182/blood-2008-09-181206

68. Bierings R., Hellen N., Kiskin N., Knipe L., Fonseca A.V., Patel B., Meli A., Rose M., Hannah M.J., Carter T. 2012. The interplay between the Rab27A effectors Slp4a and MyRIP controls hormone-evoked Weibel-Palade body exocytosis. Blood. 120, 2757-2767. https://doi.org/10.1182/blood-2012-05-429936

69. Zografou S., Basagiannis D., Papafotika A., Shirakawa R., Horiuchi H., Auerbach D., Fukuda M., Christoforidis S. 2012. A complete Rab screening reveals novel insights in Weibel-Palade body exocytosis. J. Cell. Sci. 125, 4780-4790. https://doi.org/10.1242/jcs.104174

70. Schillemans M., Karampini E., van den Eshof B.L., Gangaev A., Hofman M., van Breevoort D., Meems H., Janssen H., Mulder A.A., Jost C.R., Escher J.C., Adam R., Carter T., Koster A.J., van den Biggelaar M., Voorberg J., Bierings R. 2018. Weibel-Palade body localized syntaxin-3 modulates von Willebrand factor secretion from endothelial cells. Arterioscler. Thromb. Vasc. Biol. 38, 1549-1561. https://doi.org/10.1161/ATVBAHA.117.310701

71. Schillemans M., Karampini E., Hoogendijk A.J., Wahedi M., van Alphen F.P.J., van den Biggelaar M., Voorberg J., Bierings R. 2019. Interaction networks of Weibel-Palade body regulators syntaxin-3 and syntaxin binding protein 5 in endothelial cells. J. Proteomics. 
205, 103417 . https://doi.org/10.1016/j.jprot.2019.103417

72. Manneville J.B., Etienne-Manneville S., Skehel P., Carter T., Ogden D., Ferenczi M. 2003. Interaction of the actin cytoskeleton with microtubules regulates secretory organelle movement near the plasma membrane in human endothelial cells. J. Cell. Sci. 116, 3927-3938.

https://doi.org/10.1242/jcs.00672

73. Romani de Wit T., Rondaij M.G., Hordijk P.L., Voorberg J., van Mourik J.A. 2003. Real-time imaging of the dynamics and secretory behavior of Weibel-Palade bodies. Arterioscler. Thromb. Vasc. Biol. 23, 755-761. https://doi.org/10.1161/01.ATV.0000069847.72001.E8

74. Kawecki C., Lenting P.J., Denis C.V. 2017. von Willebrand factor and inflammation. J. Thromb. Haemost. 15, 1285-1294. https://doi.org/10.1111/jth.13696

75. Chen J., Chung D.W. 2018. Inflammation, von Willebrand factor, and ADAMTS13. Blood. 132, 141-147. https://doi.org/10.1182/blood-2018-02-769000

76. Vischer U.M., Jornot L., Wollheim C.B., Theler J.M. 1995. Reactive oxygen intermediates induce regulated secretion of von Willebrand factor from cultured human vascular endothelial cells. Blood. 85, 3164-3172.

77. Yang S., Zheng Y., Hou X. 2019. Lipoxin A4 restores oxidative stress-induced vascular endothelial cell injury and thrombosis-related factor expression by its receptor-mediated activation of Nrf2-HO-1 axis. Cell. Signal. 60, 146-153.

https://doi.org/10.1016/j.cellsig.2019.05.002

78. Avdonin P.V., Tsitrina A.A., Mironova G.Y., Avdonin P.P., Zharkikh I.L., Nadeev A.D., Goncharov N.V. 2017. Hydrogen peroxide stimulates exocytosis of von Willebrand factor in human umbilical vein endothelial cells. Biol. Bull. 44, 531-537.

https://doi.org/10.1134/s106235901705003x

79. Avdonin P.P., Trufanov S.K., Rybakova E.Y., Tsitrina A.A., Goncharov N.V., Avdonin P.V. 2021. The use of fluorescently labeled ARC1779 aptamer for assessimg the effect of $\mathrm{H}_{2} \mathrm{O}_{2}$ on von Willebrand factor exocytosis. Biochemistry (Moscow). 86, 123-131.

https://doi.org/10.1134/S0006297921020012

80. Evangelista A.M., Thompson M.D., Bolotina V.M., Tong X., Cohen R.A. 2012. Nox4- and Nox2-dependent oxidant production is required for VEGF-induced SERCA cysteine-674 S-glutathiolation and endothelial cell migration. Free Radic. Biol. Med. 53, 2327-2334. https://doi.org/10.1016/j.freeradbiomed.2012.10.546

81. Mo S.J., Son E.W., Rhee D.K., Pyo S. 2003. Modulation of TNF-alpha-induced ICAM-1 expression, NO and $\mathrm{H}_{2} \mathrm{O}_{2}$ production by alginate, allicin and ascorbic acid in human endothelial cells. Arch. Pharm. Res. 26, 244-251.

82. Bernardo A., Ball C., Nolasco L., Moake J.F., Dong J.F. 2004. Effects of inflammatory cytokines on the release and cleavage of the endothelial cell-derived ultralarge von Willebrand factor multimers under flow. Blood. 104, 100-106. doi 2004-01-0107 https://doi.org/10.1182/blood-2004-01-0107

83. Matsushita K., Yamakuchi M., Morrell C.N., Ozaki M., O'Rourke B., Irani K., Lowenstein C.J. 2005. Vascular endothelial growth factor regulation of Weibel-Palade body exocytosis. Blood. 105, 207-214. https://doi.org/10.1182/blood-2004-04-1519

84. Zhou Y.F., Eng E.T., Zhu J., Lu C., Walz T., Springer T.A. 2012. Sequence and structure relationships within von Willebrand factor. Blood. 120, 449-458. https://doi.org/10.1182/blood-2012-01-405134

85. Zhang X., Halvorsen K., Zhang C.Z., Wong W.P., Springer T.A. 2009. Mechanoenzymatic cleavage of the ultralarge vascular protein von Willebrand factor. Science. 324, 1330-1334.

https://doi.org/10.1126/science.1170905

86. Huizinga E.G., Martijn van der Plas R., Kroon J., Sixma J.J., Gros P. 1997. Crystal structure of the A3 domain of human von Willebrand factor: Implications for collagen binding. Structure. 5, 1147-1156. https://doi.org/10.1016/s0969-2126(97)00266-9

87. Shapiro S.E., Nowak A.A., Wooding C., Birdsey G., Laffan M.A., McKinnon T.A. 2014. The von Willebrand factor predicted unpaired cysteines are essential for secretion. J. Thromb. Haemost. 12, 246-254. https://doi.org/10.1111/jth.12466

88. Dong X., Leksa N.C., Chhabra E.S., Arndt J.W., Lu Q., Knockenhauer K.E., Peters R.T., Springer T.A. 2019. The von Willebrand factor D'D3 assembly and structural principles for factor VIII binding and concatemer biogenesis. Blood. 133, 1523-1533.

https://doi.org/10.1182/blood-2018-10-876300

89. Yee A., Kretz C.A. 2014. Von Willebrand factor: Form for function. Semin. Thromb. Hemost. 40, 17-27. https://doi.org/10.1055/s-0033-1363155

90. Ward S., O'Sullivan J.M., O'Donnell J.S. 2019. von Willebrand factor sialylation-A critical regulator of biological function. J. Thromb. Haemost. 17, 1018-1029. https://doi.org/10.1111/jth.14471

91. Arya M., Anvari B., Romo G.M., Cruz M.A., Dong J.F., McIntire L.V., Moake J.L., Lopez J.A. 2002. Ultralarge multimers of von Willebrand factor form spontaneous highstrength bonds with the platelet glycoprotein Ib-IX complex: Studies using optical tweezers. Blood. 99, 3971-3977. https://doi.org/10.1182/blood-2001-11-0060

92. Pushin D.M., Salikhova T.Y., Zlobina K.E., Guria G. T. 2020. Platelet activation via dynamic conformational changes of von Willebrand factor under shear. PLoS One. 15, e0234501.

https://doi.org/10.1371/journal.pone.0234501

93. Zlobina K.E., Guria G.T. 2016. Platelet activation risk index as a prognostic thrombosis indicator. Sci Rep. 6, 30508. https://doi.org/10.1038/srep30508

94. Sadler J.E. 2008. Von Willebrand factor, ADAMTS13, and thrombotic thrombocytopenic purpura. Blood. 112, $11-18$.

https://doi.org/10.1182/blood-2008-02-078170

95. Brophy T.M., Ward S.E., McGimsey T.R., Schneppenheim S., Drakeford C., O'Sullivan J.M., Chion A., Budde U., O’Donnell J.S. 2017. Plasmin cleaves von Willebrand factor at K1491-R1492 in the A1-A2 linker region in a shear- and glycan-dependent manner in vitro. Arterioscler Thromb. Vasc. Biol. 37, 845-855. https://doi.org/10.1161/ATVBAHA.116.308524

96. Preston R.J., Rawley O., Gleeson E.M., O’Donnell J.S. 2013. Elucidating the role of carbohydrate determinants in regulating hemostasis: Insights and opportunities. Blood. 121, 3801-3810.

https://doi.org/10.1182/blood-2012-10-415000 
97. Canis K., McKinnon T.A., Nowak A., Haslam S.M., Panico M., Morris H.R., Laffan M. A., Dell A. 2012. Mapping the N-glycome of human von Willebrand factor. Biochem. J. 447, 217-228. https://doi.org/10.1042/BJ20120810

98. McGrath R.T., McRae E., Smith O.P., O’Donnell J.S. 2010. Platelet von Willebrand factor-structure, function and biological importance. Br. J. Haematol. 148, 834-843. https://doi.org/10.1111/j.1365-2141.2009.08052.x

99. Schmugge M., Rand M.L., Freedman J. 2003. Platelets and von Willebrand factor. Transfus. Apher. Sci. 28, 269-277. https://doi.org/10.1016/S1473-0502(03)00046-6

100. Furby F. H., Berndt M. C., Castaldi P. A., Koutts J. 1984. Characterization of calcium-dependent binding of endogenous factor VIII/von Willebrand factor to surface activated platelets. Thromb. Res. 35, 501-511. https://doi.org/10.1016/0049-3848(84)90282-2

101. Andrews R.K., Gorman J.J., Booth W.J., Corino G.L., Castaldi P.A., Berndt M.C. 1989. Cross-linking of a monomeric 39/34-kDa dispase fragment of von Willebrand factor (Leu-480/Val-481-Gly-718) to the N-terminal region of the alpha-chain of membrane glycoprotein Ib on intact platelets with bis(sulfosuccinimidyl) suberate. Biochemistry. 28, 8326-8336. https://doi.org/10.1021/bi00447a010

102. Yakushkin V.V., Zyuryaev I.T., Khaspekova S.G., Sirotkina O.V., Ruda M.Y., Mazurov A.V. 2011. Glycoprotein IIb-IIIa content and platelet aggregation in healthy volunteers and patients with acute coronary syndrome. Platelets. 22, 243-251.

https://doi.org/10.3109/09537104.2010.547959

103. Naimushin Y.A., Mazurov A.V. 2004. Von Willebrand factor can support platelet aggregation via interaction with activated GPIIb-IIIa and GPIb. Platelets. 15, 419-425. https://doi.org/10.1080/09537100410001721333

104. Wu Y.P., Vink T., Schiphorst M., van Zanten G.H., IJsseldijk M.J., de Groot P.G., Sixma J.J. 2000. Platelet thrombus formation on collagen at high shear rates is mediated by von Willebrand factor-glycoprotein Ib interaction and inhibited by von Willebrand factorglycoprotein IIb/IIIa interaction. Arterioscler. Thromb. Vasc. Biol. 20, 1661-1667. https://doi.org/10.1161/01.atv.20.6.1661

105. Kaneva V.N., Dunster J.L., Volpert V., Ataullahanov F., Panteleev M.A., Nechipurenko D.Y. 2021. Modeling thrombus shell: Linking adhesion receptor properties and macroscopic dynamics. Biophys. J. 120, 334-351. https://doi.org/10.1016/j.bpj.2020.10.049

106. Sadler J.E. 2005. New concepts in von Willebrand disease. Annu. Rev. Med. 56, 173-191.

https://doi.org/10.1146/annurev.med.56.082103.104713

107. Jilma B., Eichler H.G., Vondrovec B., Breiteneder H., Kyrle P.A., Kitzweger E., Kapiotis S., Speiser W. 1996. Effects of desmopressin on circulating P-selectin. $\mathrm{Br}$. J. Haematol. 93, 432-436. https://doi.org/10.1046/j.1365-2141.1996.5031040.x

108. Murphy S.J.X., Lim S.T., Hickey F., Kinsella J.A., Smith D.R., Tierney S., Egan B., Feeley T.M., Murphy S.M., Collins D.R., Coughlan T., O’Neill D., Harbison J.A., Madhavan P., O’Neill S.M., Colgan M.P.,
O’Donnell J.S., O'Sullivan J.M., Hamilton G., McCabe D.J.H. 2021. von Willebrand factor antigen, von Willebrand factor propeptide, and ADAMTS13 in carotid stenosis and their relationship with cerebral microemboli. Thromb. Haemost. 121, 86-97. https://doi.org/10.1055/s-0040-1715440

109. Vischer U.M., Ingerslev J., Wollheim C.B., Mestries J.C., Tsakiris D.A., Haefeli W.E., Kruithof E.K. 1997. Acute von Willebrand factor secretion from the endothelium in vivo: Assessment through plasma propeptide (vWf:AgII) levels. Thromb. Haemost. 77, 387-393.

110. Kaufmann J.E., Vischer U.M. 2003. Cellular mechanisms of the hemostatic effects of desmopressin (DDAVP). J. Thromb. Haemost. 1, 682-689.

111. Jilma B., Pernerstorfer T., Dirnberger E., Stohlawetz P., Schmetterer L., Singer E.A., Grasseli U., Eichler H.G., Kapiotis S. 1998. Effects of histamine and nitric oxide synthase inhibition on plasma levels of von Willebrand factor antigen. J. Lab. Clin. Med. 131, 151-156. https://doi.org/10.1016/s0022-2143(98)90157-3

112. Leitner G.C., Schmetterer L., Kapiotis S., Jilma B. 2010. Effects of endothelin-1 and phenylephrine on plasma levels of von Willebrand factor and protein $\mathrm{S}$. Thromb. Res.125, e5-8. https://doi.org/10.1016/j.thromres.2009.08.004

113. Reiter R.A., Varadi K., Turecek P.L., Jilma B., Knobl P. 2005. Changes in ADAMTS13 (von-Willebrand-factor-cleaving protease) activity after induced release of von Willebrand factor during acute systemic inflammation. Thromb. Haemost. 93, 554-558. https://doi.org/10.1160/TH04-08-0467

114. Buchtele N., Kovacevic K.D., Brostjan C., Schwameis M., Hayden H., Derhaschnig U., Firbas C., Jilma B., Schoergenhofer C. 2020. Differential osteoprotegerin kinetics after stimulation with desmopressin and lipopolysaccharides in vivo. Thromb. Haemost. 120, 11081115. https://doi.org/10.1055/s-0040-1712448

115. Millar C.M., Riddell A.F., Brown S.A., Starke R., Mackie I., Bowen D.J., Jenkins P.V., van Mourik J.A. 2008. Survival of von Willebrand factor released following DDAVP in a type 1 von Willebrand disease cohort: Influence of glycosylation, proteolysis and gene mutations. Thromb. Haemost. 99, 916-924. https://doi.org/10.1160/TH07-09-0565

116. Badirou I., Kurdi M., Rayes J., Legendre P., Christophe O.D., Lenting P.J., Denis C.V. 2010. von Willebrand factor clearance does not involve proteolysis by ADAMTS-13. J. Thromb. Haemost. 8, 2338-2340. https://doi.org/10.1111/j.1538-7836.2010.04012.x

117. O'Sullivan J.M., Ward S., Lavin M., O’Donnell J.S. 2018. von Willebrand factor clearance - biological mechanisms and clinical significance. Br. J. Haematol. 183, 185-195. https://doi.org/10.1111/bjh.15565

118. Lenting P.J., Westein E., Terraube V., Ribba A.S., Huizinga E.G., Meyer D., de Groot P.G., Denis C.V. 2004. An experimental model to study the in vivo survival of von Willebrand factor. Basic aspects and application to the R1205H mutation. J. Biol. Chem. 279, 12102-12109. https://doi.org/10.1074/jbc.M310436200

119. van Schooten C.J., Shahbazi S., Groot E., Oortwijn B.D., van den Berg H.M., Denis C.V., Lenting P.J. 2008. 
Macrophages contribute to the cellular uptake of von Willebrand factor and factor VIII in vivo. Blood. 112, 1704-1712. https://doi.org/10.1182/blood-2008-01-133181

120. Chion A., O’Sullivan J.M., Drakeford C., Bergsson G., Dalton N., Aguila S., Ward S., Fallon P.G., Brophy T.M., Preston R.J., Brady L., Sheils O., Laffan M., McKinnon T.A., O’Donnell J.S. 2016. N-linked glycans within the A2 domain of von Willebrand factor modulate macrophage-mediated clearance. Blood. 128, 1959-1968.

https://doi.org/10.1182/blood-2016-04-709436

121. van Schooten C.J., Denis C.V., Lisman T., Eikenboom J.C., Leebeek F.W., Goudemand J., Fressinaud E., van den Berg H.M., de Groot P.G., Lenting P.J. 2007. Variations in glycosylation of von Willebrand factor with O-linked sialylated $\mathrm{T}$ antigen are associated with its plasma levels. Blood. 109, 2430-2437. https://doi.org/10.1182/blood-2006-06-032706

122. Sodetz J.M., Pizzo S.V., McKee P.A. 1977. Relationship of sialic acid to function and in vivo survival of human factor VIII/von Willebrand factor protein. J. Biol. Chem. 252, 5538-5546.

123. Ward S.E., O'Sullivan J.M., Drakeford C., Aguila S., Jondle C.N., Sharma J., Fallon P.G., Brophy T.M., Preston R.J.S., Smyth P., Sheils O., Chion A., O'Donnell J.S. 2018. A novel role for the macrophage galactose-type lectin receptor in mediating von Willebrand factor clearance. Blood. 131, 911-916.

https://doi.org/10.1182/blood-2017-06-787853

124. Grewal P.K. 2010. The Ashwell-Morell receptor. Methods Enzymol. 479, 223-241. https://doi.org/10.1016/S0076-6879(10)79013-3

125. Grewal P.K., Uchiyama S., Ditto D., Varki N., Le D.T., Nizet V., Marth J.D. 2008. The Ashwell receptor mitigates the lethal coagulopathy of sepsis. Nat. Med. 14, 648-655. https://doi.org/10.1038/nm1760

126. Denis C.V., Lenting P.J. 2018. VWF clearance: It's glycomplicated. Blood. 131, 842-843. https://doi.org/10.1182/blood-2018-01-824904

127. Pegon J.N., Kurdi M., Casari C., Odouard S., Denis C.V., Christophe O.D., Lenting P.J. 2012. Factor VIII and von Willebrand factor are ligands for the carbohydrate-receptor Siglec-5. Haematologica. 97, 1855-1863. https://doi.org/10.3324/haematol.2012.063297

128. Lock K., Zhang J., Lu J., Lee S.H., Crocker P.R. 2004. Expression of CD33-related siglecs on human mononuclear phagocytes, monocyte-derived dendritic cells and plasmacytoid dendritic cells. Immunobiology. 209, 199-207. https://doi.org/10.1016/j.imbio.2004.04.007

129. Jandus C., Simon H.U., von Gunten S. 2011. Targeting siglecs-a novel pharmacological strategy for immuno- and glycotherapy. Biochem. Pharmacol. 82, $323-332$.

https://doi.org/10.1016/j.bcp.2011.05.018

130. Rydz N., Swystun L.L., Notley C., Paterson A.D., Riches J.J., Sponagle K., Boonyawat B., Montgomery R.R., James P.D., Lillicrap D. 2013. The C-type lectin receptor CLEC4M binds, internalizes, and clears von Willebrand factor and contributes to the variation in plasma von Willebrand factor levels. Blood.
121, 5228-5237. https://doi.org/10.1182/blood-2012-10-457507

131. Khoo U.S., Chan K.Y., Chan V.S., Lin C.L. 2008. DC-SIGN and L-SIGN: The SIGNs for infection. J. Mol. Med. (Berl.). 86, 861-874. https://doi.org/10.1007/s00109-008-0350-2

132. Rastegarlari G., Pegon J.N., Casari C., Odouard S., Navarrete A.M., Saint-Lu N., van Vlijmen B.J., Legendre P., Christophe O.D., Denis C.V., Lenting P.J. 2012. Macrophage LRP1 contributes to the clearance of von Willebrand factor. Blood. 119, 2126-2134. https://doi.org/10.1182/blood-2011-08-373605

133. Zani I.A., Stephen S.L., Mughal N.A., Russell D., Homer-Vanniasinkam S., Wheatcroft S.B., Ponnambalam S. 2015. Scavenger receptor structure and function in health and disease. Cells. 4, 178-201. https://doi.org/10.3390/cells4020178

134. Swystun L.L., Lai J.D., Notley C., Georgescu I., Paine A.S., Mewburn J., Nesbitt K., Schledzewski K., Geraud C., Kzhyshkowska J., Goerdt S., Hopman W., Montgomery R.R., James P.D., Lillicrap D. 2018. The endothelial cell receptor stabilin-2 regulates VWF-FVIII complex half-life and immunogenicity. J. Clin. Invest. 128, 4057-4073. https://doi.org/10.1172/JCI96400

135. Fazavana J., Brophy T.M., Chion A., Cooke N., Terraube V., Cohen J., Parng C., Pittman D., Cunningham O., Lambert M., O'Donnell J.S., O'Sullivan J.M. 2020. Investigating the clearance of VWF A-domains using site-directed PEGylation and novel N-linked glycosylation. J. Thromb. Haemost. 18, 1278-1290. https://doi.org/10.1111/jth.14785

136. Wohner N., Muczynski V., Mohamadi A., Legendre P., Proulle V., Ayme G., Christophe O.D., Lenting P.J., Denis C.V., Casari C. 2018. Macrophage scavenger receptor SR-AI contributes to the clearance of von Willebrand factor. Haematologica. 103, 728-737. https://doi.org/10.3324/haematol.2017.175216

137. Koutts J., Walsh P.N., Plow E.F., Fenton J.W., 2nd, Bouma B.N., Zimmerman T.S. 1978. Active release of human platelet factor VIII-related antigen by adenosine diphosphate, collagen, and thrombin. J. Clin. Invest. 62, 1255-1263. https://doi.org/10.1172/JCI109246

138. Fernandez M.F., Ginsberg M.H., Ruggeri Z.M., Batlle F.J., Zimmerman T.S. 1982. Multimeric structure of platelet factor VIII/von Willebrand factor: The presence of larger multimers and their reassociation with thrombin-stimulated platelets. Blood. 60, 1132-1138.

139. Nichols T.C., Bellinger D.A., Reddick R.L., Read M.S., Koch G.G., Brinkhous K.M., Griggs T.R. 1991. Role of von Willebrand factor in arterial thrombosis. Studies in normal and von Willebrand disease pigs. Circulation. 83, IV56-64.

140. Keesler D.A., Flood V.H. 2018. Current issues in diagnosis and treatment of von Willebrand disease. Res. Pract. Thromb. Haemost. 2, 34-41. https://doi.org/10.1002/rth2.12064

141. O'Donnell J.S. 2020. Low VWF: Insights into pathogenesis, diagnosis, and clinical management. Blood Adv. 4, 3191-3199. https://doi.org/10.1182/bloodadvances.2020002038

142. Eikenboom J.C., Matsushita T., Reitsma P.H., Tuley E.A., Castaman G., Briet E., Sadler J.E. 1996. Dominant 
type 1 von Willebrand disease caused by mutated cysteine residues in the D3 domain of von Willebrand factor. Blood. 88, 2433-2441.

143. Eikenboom J., Hilbert L., Ribba A.S., Hommais A., Habart D., Messenger S., Al-Buhairan A., Guilliatt A., Lester W., Mazurier C., Meyer D., Fressinaud E., Budde U., Will K., Schneppenheim R., Obser T., Marggraf O., Eckert E., Castaman G., Rodeghiero F., Federici A.B., Batlle J., Goudemand J., Ingerslev J., Lethagen S., Hill F., Peake I., Goodeve A. 2009. Expression of 14 von Willebrand factor mutations identified in patients with type 1 von Willebrand disease from the MCMDM-1VWD study. J. Thromb. Haemost. 7, 1304-1312. https://doi.org/10.1111/j.1538-7836.2009.03486.x

144. James P., Lillicrap D. 2008. The role of molecular genetics in diagnosing von Willebrand disease. Semin. Thromb. Hemost. 34, 502-508. https://doi.org/10.1055/s-0028-1103361

145. Zimmerman T.S., Dent J.A., Ruggeri Z.M., Nannini L.H. 1986. Subunit composition of plasma von Willebrand factor. Cleavage is present in normal individuals, increased in IIA and IIB von Willebrand disease, but minimal in variants with aberrant structure of individual oligomers (types IIC, IID, and IIE). J. Clin. Invest. 77, 947-951. https://doi.org/10.1172/JCI112394

146. Schneppenheim R., Budde U., Ruggeri Z.M. 2001. A molecular approach to the classification of von Willebrand disease. Best Pract. Res. Clin. Haematol. 14, $281-298$. https://doi.org/10.1053/beha.2001.0134

147. Schneppenheim R., Budde U. 2005. Phenotypic and genotypic diagnosis of von Willebrand disease: A 2004 update. Semin. Hematol. 42, 15-28. https://doi.org/10.1053/j.seminhematol.2004.10.002

148. Fogarty H., Doherty D., O’Donnell J. S. 2020. New developments in von Willebrand disease. Br. J. Haematol. 191, 329-339. https://doi.org/10.1111/bjh.16681

149. Sadler J.E., Budde U., Eikenboom J.C., Favaloro E.J., Hill F.G., Holmberg L., Ingerslev J., Lee C.A., Lillicrap D., Mannucci P.M., Mazurier C., Meyer D., Nichols W.L., Nishino M., Peake I.R., Rodeghiero F., Schneppenheim R., Ruggeri Z.M., Srivastava A., Montgomery R.R., Federici A.B. 2006. Update on the pathophysiology and classification of von Willebrand disease: A report of the Subcommittee on von Willebrand Factor. J. Thromb. Haemost. 4, 2103-2114. https://doi.org/10.1111/j.1538-7836.2006.02146.x

150. Stepanian A., Ribba A.S., Lavergne J.M., Fressinaud E., Juhan-Vague I., Mazurier C., Girma J.P., Meyer D. 2003. A new mutation, S1285F, within the A1 loop of von Willebrand factor induces a conformational change in A1 loop with abnormal binding to platelet GPIb and botrocetin causing type $2 \mathrm{M}$ von Willebrand disease. Br. J. Haematol. 120, 643-651. https://doi.org/10.1046/j.1365-2141.2003.04168.x

151. Castaman G., Giacomelli S.H., Jacobi P., Obser T., Budde U., Rodeghiero F., Haberichter S.L., Schnep- penheim R. 2010. Homozygous type 2N R854W von Willebrand factor is poorly secreted and causes a severe von Willebrand disease phenotype. J. Thromb. Haemost. 8, 2011-2016. https://doi.org/10.1111/j.1538-7836.2010.03971.x

152. Veyradier A., Boisseau P., Fressinaud E., Caron C., Ternisien C., Giraud M., Zawadzki C., Trossaert M., Itzhar-Baikian N., Dreyfus M., d'Oiron R., BorelDerlon A., Susen S., Bezieau S., Denis C. V., Goudemand J., French Reference Center for von Willebrand d. 2016. A laboratory phenotype/genotype correlation of 1167 french patients from 670 families with von Willebrand disease: A new epidemiologic picture. Medicine (Baltimore). 95, e3038.

https://doi.org/10.1097/MD.0000000000003038

153. Mehta R., Athar M., Girgis S., Hassan A., Becker R.C. 2019. Acquired von Willebrand syndrome (AVWS) in cardiovascular disease: A state of the art review for clinicians. J. Thromb. Thrombolysis. 48, 14-26. https://doi.org/10.1007/s11239-019-01849-2

154. Vincentelli A., Susen S., Le Tourneau T., Six I., Fabre O., Juthier F., Bauters A., Decoene C., Goudemand J., Prat A., Jude B. 2003. Acquired von Willebrand syndrome in aortic stenosis. N. Engl. J. Med. 349, 343-349. https://doi.org/10.1056/NEJMoa022831

155. Hayakawa M., Matsumoto M. 2020. Acquired von Willebrand syndrom. Rinsho Ketsueki. 61, 809-817. https://doi.org/10.11406/rinketsu.61.809

156. Moake J.L., McPherson P.D. 1989. Abnormalities of von Willebrand factor multimers in thrombotic thrombocytopenic purpura and the hemolytic-uremic syndrome. Am. J. Med. 87, 9N-15N.

157. Sadler J.E. 2006. Thrombotic thrombocytopenic purpura: A moving target. Hematology Am. Soc. Hematol. Educ. Program. 415-420. https://doi.org/10.1182/asheducation-2006.1.415

158. Gupta M., Feinberg B.B., Burwick R.M. 2018. Thrombotic microangiopathies of pregnancy: Differential diagnosis. Pregnancy Hypertens. 12, 29-34. https://doi.org/10.1016/j.preghy.2018.02.007

159. Zheng X.L. 2015. ADAMTS13 and von Willebrand factor in thrombotic thrombocytopenic purpura. Annu. Rev. Med. 66, 211-225. https://doi.org/10.1146/annurev-med-061813-013241

160. Foreman K.E., Vaporciyan A.A., Bonish B.K., Jones M.L., Johnson K.J., Glovsky M.M., Eddy S.M., Ward P.A. 1994. C5a-induced expression of P-selectin in endothelial cells. J. Clin. Invest. 94, 1147-1155. https://doi.org/10.1172/JCI117430

161. Gragnano F., Golia E., Natale F., Bianchi R., Pariggiano I., Crisci M., Diana V., Fimiani F., Limongelli G., Russo M., Cirillo P., Calabro P. 2017. Von Willebrand factor and cardiovascular disease: From a biochemical marker to an attractive therapeutic target. Curr. Vasc. Pharmacol. 15, 404-415. https://doi.org/10.2174/1570161115666170201114835

Translated by E. Makeeva 